\title{
Withaferin A - A natural multifaceted therapeutic compound
}

\author{
Sangeetha Vinod, Kalaiselvi Senthil* \\ Department of Biochemistry, Biotechnology and Bioinformatics, School of Biosciences, Avinashilingam Institute for Home \\ Science and Higher Education for Women, Coimbatore- 641043, Tamil Nadu, India
}

Received: January 20, 2021 Revised: March 06, 2021 Accepted: March 08, 2021 Published: March 26, 2021

*Correspondence Author: Kalaiselvi Senthi Email: kalaiselvi_bc@avinuty.ac.in Immunomodulatory, Anti-Viral.

\begin{abstract}
COVID 19, which has led to the death of millions of people, is still spreading worldwide. Development of any new drug after proper trial is much time consuming. This present global pandemic situation has led the researchers around the world to run behind various existing antiviral and immunomodulatory natural compounds to overcome this contagious disease. Withania somnifera (ashwagandha) that is being used in Ayurvedic medicine for several ailments since several years is also said to pocess anti-viral activity. Many of its metabolites are being studied individually for its efficacy against the dreadful disease. Withaferin A, a steroidal lactone compound from ashwagandha is one among the important metabolites which is being investigated for its anti-viral activity. Thus because of its wide spectrum of medicinal properties it has now become an attractive drug candidate for several preclinical studies. This increase in the demand for withaferin $\mathrm{A}$ has chanelled its way towards in vitro propagation of the plant W. somnifera and trials on various strategies to increase the yield in terms of plant biomass as well as the withaferin content in the plants thus making it a better alternative to field grown plants. Thus this article reviews in depth on the important medicinal properties of withaferin A, its demand in Ayurveda industry and the in vitro strategies that are being carried out to overcome the demand.
\end{abstract}

\section{INTRODUCTION}

Withania somnifera Dunal (Ashwagandha), belonging to the family Solanaceae, has been known for its array of therapeutic activities. It is an important medicinal herb in the traditional medicine. Various studies have demonstrated that Withania, in its reasonable dose is non-toxic, safe and an edible herb to be used as an adaptogenic tonic. Until now, 12 alkaloids, 35 withanolides and several sitoindosides have been isolated from this plant and structures elucidated (Mishra et al., 2000). Of these withanolides are of prime importance (Matsuda et al., 2001). Withanolides, though are a group of naturally occurring steroids specific to the Solanaceae family are also reported in fewer amounts in Lamiaceae, Taccaceae and Fabaceae families. It is the major chemical constituent of the Withania genus though is reported in small quantities from Physalis, Dature, Nicandra, Dunalia, Lycium, Tubocapsicum and Jaborosa genus (Cordero et al., 2009). Ashwagandha extracts from various parts like leaf, root and shoots have shown the presence of withanolides, of which withaferin A, withanolide A, withanolide $\mathrm{D}$ and withanone are of prime importance.

Withaferin A (WA), a white crystalline substance with maximum absorption in the UV region, is the first member of the withanolides group to be isolated from the leaves of Indian W. somnifera. It was then later isolated from an Israeli variety, characterized and given the name Withaferin A (David et al., 1965). Being the major pharmacologically active withanolide, it is the most studied molecule (Choudhary et al., 2010). WA with potent anti-viral and immunomodulatory activity has also been proved as a potent inhibitor of SARSCoV2 main protease (Chandel et al., 2020) thus becoming an important molecule under focus in this pandemic situation. This review highlights the various studies undergone on this wonder compound thus highlighting the deficiencies in our knowledge. This would further help researchers to direct studies to bridge the gaps.

\section{STRUCTURE AND DERIVATIVES OF WITHAFERIN A IN RELATION TO ITS ACTIVITY}

Withanolides are naturally occurring C28 steroids with an ergostane backbone in which the $22^{\text {nd }}$ and $26^{\text {th }}$ carbon are oxidized to form a 6 membered lactone ring. Withaferin A ( $4 \beta, 27$-dihydroxy-1-oxo- $5 \beta, 6 \beta$-epoxywitha-2-24-dienolide) is a bioactive compound classified as withanolide. Being one of the most bioactive compound, it is necessary to have a clear

Copyright: (C) The authors. This article is open access and licensed under the terms of the Creative Commons Attribution License (http://creativecommons.org/licenses/by/4.0/) which permits unrestricted, use, distribution and reproduction in any medium, or format for any purpose, even commercially provided the work is properly cited. Attribution — You must give appropriate credit, provide a link to the license, and indicate if changes were made. 
insight into the molecular mechanisms underlying its broad range of bioactivities. Therefore, a lot of effort has been made to explore the intracellular effects of WA and to characterize its target protein (Vanden Berghe et al., 2012). The structure of WA also contributes to its cytotoxic activity. WA is a C5, C6 epoxy compound with hydroxyl groups on C4 and C27. The skeletal nature of WA was obtained after several dehydrogenation experiments with selenium on the product obtained by lithium aluminium hydride reduction of dihydro withaferin A (Lavie et al., 1965a, Lavie et al., 1965b). The 2D structure of withaferin $\mathrm{A}$ is retrieved from pubchem and presented as figure 1 (https:// pubchem.ncbi.nlm.nih.gov/compound/Withaferin-A-Withania somnifera). The studies on WA and 9 of its derivatives revealed 4-dehydro withaferin A and withaferin A diacetate as the most potent agents exhibiting equal inhibitory effect on thymidine, uridine, and L-valine incorporation in nucleic acid synthesis. Further the double bond between C2-3 was responsible for the cytotoxic effect, the dissociation of which lead to a decrease in the activity of all the derivatives. Also an increase in the activity was observed on the addition of a carbonyl group at $\mathrm{C} 4$ position. Whereas the removal of $\mathrm{OH}$ group at $\mathrm{C} 27$ or the dissociation of the double bond between C24-25 did not cause any change in the activity (Fuska et al., 1984). But, a modification at the OH group of $\mathrm{C} 27$ by a subsequent reversible addition fragmentation chain transfer (RAFT) polymerization with hydrophilic N,N-dimethyl acrylamide yielded a completely water soluble conjugate of WA. Thus overcoming its poor solubility that limits its use (Van Herck et al., 2019). Similar studies on the structure activity relationships of withaferin A, withanolide D and its semisynthetic analogues prepared by chemical and microbial transformations revealed the increased efficiency of withaferin A derivatives compared to its corresponding withanolide $\mathrm{D}$ derivatives.

The study on the cytotoxicity and heat shock inducing activity revealed the importance of the ring A structure for its bioactivities. This study proved that the modification of the withanolide scaffold can increase its heat shock inducing activity (Wijeratne et al., 2014). Study on the in vitro cytotoxic effect of WA analogues obtained upon modification of the ring A structure reported a 35 fold increase in activity in a 3-azido

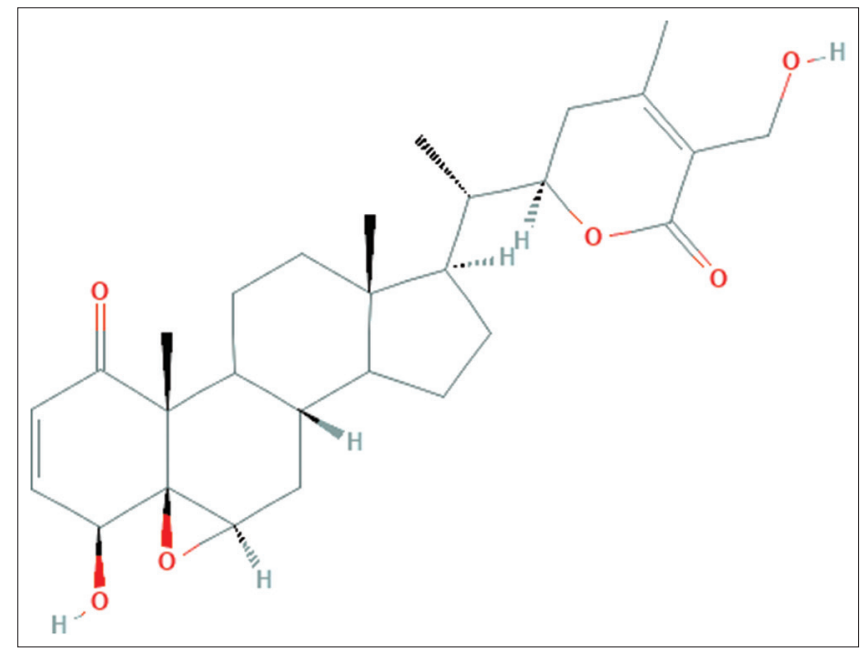

Figure 1: 2D structure of Withaferin A analogue of WA compared to the parent molecule (Yousuf et al., 2011). Metabolite studies on W. somnifera grown under soil free aeroponic condition resulted in the isolation two new WA derivatives $3 \alpha$-(uracil-1-yl)-2,3-dihydroWA and 3 $\beta$-(adenin-9yl)-2,3-dihydroWA along with ten other structurally diverse withanolides which were also referred to as WA. The structure of these compounds was elucidated on the basis of high resolution mass and NMR spectroscopy (Xu et al., 2011).

2,3- dihydro- $3 \beta$-methoxy WA (3 $\beta \mathrm{mWi}-\mathrm{A})$, another derivative of WA was found to lack the cytotoxic property of WA but it helped in the induction of anti-stress and pro survival signaling. Thus $3 \beta \mathrm{mWi}$-A was found to protect normal cells against stress (Chaudhary et al., 2019). A few chlorinated forms of WA like $6 \alpha$-chloro- $5 \beta$-hydroxy WA, (22R)-5 $\beta$-formyl-6 $\beta, 27$-dihydroxy-1oxo-4-norwith-24-enolide, 2,3-dihydrowithaferin were also isolated from ethyl acetate fraction of $W$. somnifera and their structures elucidated by crystallographic studies (Tong et al., 2011).

\section{THERAPEUTIC POTENTIAL OF WITHAFERIN A}

Ashwagandha is a cost effective adaptogenic drug that is being used effectively to combat the various complications of stress. Since stress is an underlying cause of most of the health issues, study on the natural ways to overcome it has become a necessity. WA has been reported to increase the antioxidant potential, prevent gastric ulcer and hepatotoxicity induced by stress. Many investigations has been carried out to explore the multifaceted properties of WA and the results showed its significant pharmacological properties (Shrilata et al., 2017). The ADME studies using QikProp software revealed that WA is a small molecule capable of exhibiting antagonistic and agonistic activities without any side effects to the organism (Vaishnavi et al., 2012). Further the oral bioavailability of WA studied in male rats (Dai et al., 2019) showed bioavailability of around $32.4 \%$ with a strong first pass metabolism. The most important medicinal properties studied so far are explained below and a few less reported studies are presented in table 1 .

\section{Anti-oxidant and Anti-inflammatory Activities}

The studies by Mandal et al (2010) has proved the pharmacognostic and free radical scavenging efficiency of the different parts of the plant W. somnifera. The active principles of Withania somnifera (sitoindosides VII-X and WA) showed anti-oxidant activity comparable to the standard drug deprenyl (Bhattacharya et al., 1997). The glycowithanolides of Withania somnifera was also found to reverse the effects of chronic stress. The oral administration of glycowithanolides lhour before the induction of foot shock stress in rats bought back the SOD and LPO activities to normal (Bhattacharya et al., 2001). WA has proved to reduce oxidative stress against DEN induced hepatocellular carcinoma in rats (Murugan et al., 2015). A comparative decrease in the levels of reactive oxygen species was observed in WA treated rats.

The anti-inflammatory activity of $W$. somnifera is attributed to the presence of its major biologically active steroid, WA (Patel 
Table 1: Therapeutic properties of Withaferin A

\begin{tabular}{|c|c|c|}
\hline S. No. & Reported activity & Model organism \\
\hline 1. & Analgesic & $\begin{array}{l}\text { Abdominal constricted mice (Sabina et al., } \\
\text { 2009) }\end{array}$ \\
\hline 2. & Anti-pyretic & $\begin{array}{l}\text { Yeast induced pyrexia mice (Sabina et al., } \\
2009 \text { ) }\end{array}$ \\
\hline 3. & Ulcerogenic effect & Gastric ulceration mice (Sabina et al., 2009) \\
\hline 4. & $\begin{array}{l}\text { Anti-platelet, } \\
\text { anti-coagulant }\end{array}$ & $\begin{array}{l}\text { TNF } \alpha \text { activated HUVEC cells ( } K u \text { \& Bae, } \\
2014 a \text { ) }\end{array}$ \\
\hline 5. & $\begin{array}{l}\text { Endothelial protein } \\
\mathrm{C} \text { receptor shedding }\end{array}$ & $\begin{array}{l}\text { TNF } \alpha \text { activated HUVEC cells (Ku et al., } \\
2014 b \text { ) }\end{array}$ \\
\hline 6. & $\begin{array}{l}\text { Amyotrophic lateral } \\
\text { sclerosis }\end{array}$ & SOD1 $1^{\mathrm{G} 93 \mathrm{~A}}$ mouse model (Dutta et al., 2018) \\
\hline 7. & $\begin{array}{l}\text { Advanced } \\
\text { osteosarcoma }\end{array}$ & $\begin{array}{l}\text { Human patients with osteosarcoma (Pires } \\
\text { et al., 2019) }\end{array}$ \\
\hline 8. & Prostrate cancer & $\begin{array}{l}\text { PC3 cell lines (Setty Balakrishnan et al., } \\
2017 \text { ) }\end{array}$ \\
\hline 9. & Arthritis & Mice (Sabina et al., 2008) \\
\hline 10. & Osteoporosis & Mice (Khedgikar et al., 2013) \\
\hline 11. & Diuretic & Laboratory animals (Benjumea et al., 2009) \\
\hline 12. & Thyroid cancer & $\begin{array}{l}\text { DR081-1 xenograft mice (Samadi et al., } \\
\text { 2010) }\end{array}$ \\
\hline 13. & Obesity & $\begin{array}{l}\text { High fat diet induced obese mice } \\
\text { (Dutta et al., 2019) }\end{array}$ \\
\hline 14. & Renoprotective & $\begin{array}{l}\text { Male swiss albino mice (Peddakkulappagari } \\
\text { et al., 2019) }\end{array}$ \\
\hline 15. & Cardioprotective & Male wild mice (Guo et al., 2019) \\
\hline 16. & Lung cancer & Cancer cell lines (Hsu et al., 2019) \\
\hline 17. & Alcohol abstinence & Rats (Kotagale et al., 2018) \\
\hline
\end{tabular}

et al., 2015a). In raw 264.7 cells, WA was found to inhibit LPS induced expression of both nitric oxide synthase (iNOS) protein and its mRNA. Oh et al (Oh et al., 2008) examined the mechanism by which WA inhibits iNOS gene expression, and suggested that WA inhibited inflammation through inhibition of NO production and iNOS expression, by blocking Akt and subsequently downregulating $\mathrm{NF} \kappa \mathrm{B}$ activity.

\section{Anti- microbial Activity}

The aqueous and organic extracts of the leaf, stem and root powders of $W$. somnifera are reported with potent inhibitory activity against the fungal species Fusarium oxysporum and Radicis lycopersici (Nefzi \& Ben Abdallah, 2016). Kumari \& Gupta (Kumari \& Gupta, 2015) has reported the inhibitory effect of W. somnifera root extract towards E. coli showing maximum up to $57.40 \%$ inhibition. The inhibitory activity of WA is due to its reaction with the SH group of the enzymes and metabolites required by the organisms. Further it was observed that this activity of WA is blocked by the presence of glutathione in the media (Budhiraja et al., 2000).

Human papilloma virus (HPV), the cause of cervical cancer, has been reported to be the main cause of cancer death in women worldwide. The high risk HPV 18 was found to inactivate the p53 (tumor suppressor) protein by its interaction through E6 oncoprotein. Since WA has been used traditionally for the cure of various cancers, its interaction with the oncoprotein was studied. The docking results revealed that WA interacts with the residues $108-117$ of the $\mathrm{p} 53$ binding site on E6 oncoprotein, thus reversing to the normal functioning of p53 (Kumar et al., 2015). Another simulation study exhibited the binding potential of the terminal hydroxyl groups of WA to sites on DNA polymerase of Herpes simplex virus. WA was predicted to bind to the amino acid residues Gln 617, Gln 618, Asn 815and Tyr 818 which are essential for the functioning of the enzyme. Thus WA can be used as a potent anti-herpetic drug (Grover et al., 201 la).

COVID 19 is a transmissible severe acute respiratory syndrome caused by SARS-CoV-2 virus. Various anti-viral compounds and active phytoconstituents approved by FDA (Chandel et al., 2020) and nearly forty chemical constituents of W. somnifera were studied using molecular dynamic simulation for its activity against main protease protein of SARS-CoV-2 (Tripathi et al., 2020). Withaferin A displayed a strong interaction towards the main protease, spike glycoprotein and RNA dependent RNA polymerase of SARS-CoV-2, with a binding energy of $-11.242 \mathrm{kcal} / \mathrm{mol},-9.631 \mathrm{kcal} / \mathrm{mol}$ and $-9.27 \mathrm{kcal} / \mathrm{mol}$ respectively (Pandit, 2020). Withaferin A was shown to interact with eleven residues Thr 24, Thr25, His 41, Cys 44, Ser 46, Met 49, Phe 140,Leu 141,Asn 142,His 164 and Glu 166 of main protease Mpro with residues(Sharma \& Deep, 2020). Withaferin A of W. somnifera has also been reported to target and repress TMPRSS2 protein which acts as a gateway for entry of viruses into host cells (Wadhwa et al., 2020) and the cellular receptor GRP78 protein which facilitates viral entry into cells (Sudeep, 2020). The severity of this infectious disease was found to be increased in aged people and people with cancer or other comorbidities. Administration of withaferin A was found to bind the viral protein and thereby inhibiting host ACE2 receptor, the downregulation of which leads to an increase in the spread of the disease (Straughn, 2020).

Leishmaniasis, an endemic disease caused by protozoan leishmania has now become an area of concern since a few species like L. donovani has developed resistance to the available drugs. Thus making it difficult to cure and therefore there is an urge to discover new drugs that can target different sites of the protozoan and thus cure the disease. Molecular dynamic studies has revealed the inhibitory activity of WA on leishmanial protein kinase $\mathrm{C}$, the target protein for anti- leishmanial drugs (Grover et al., 2012). Another important enzyme that can be targeted for developing an effective anti-leishmanial drug is Pteridine reductase 1 (PTRl). The molecular docking studies of WA against PTR 1 showed the binding efficacy with lowest binding energy of $-6.73 \mathrm{~kJ} / \mathrm{mol}$ (Chandrasekaran et al., 2015). Due to structural similarity between the PTRl and DHFR-TS, the inhibitor that targets PTRl can also target DHFR-TS. Thus the molecular dynamic studies by (Vadloori et al., 2018) against Dihydrofolate reductase- thymidylate synthase (DHFR- TS) revealed two binding sites of WA one on DHFR and another on TS domain both $40 \AA$ apart.

\section{Anti -diabetic Activity}

Withaferin was found to combat the palmitic acid induced oxidative stress effect and thus increase the viability of HUVEC cells in a dose dependent manner. This suppression of oxidative 
stress and inflammation protects the cells against endothelial insulin resistance (Batumalaie et al., 2016). In the presence of Insulin, exposure to palmitic acid generally inhibited insulin mediated IRS-1 tyrosine phosphorylation, which leads to the deterioration of downstream insulin. This inhibitory effect was mitigated by the pre-treatment of the cells with WA. Jonathan (Jonathan et al., 2015) reported the increased efficiency of WA for the uptake of glucose by the skeletal myotubes among the six withanolides studied. Thus, proving its role in the anti-diabetic activity of the plant. Further he also reported the increased efficiency of the leaf extracts for the uptake of glucose than the root extracts. The role of WA was further revealed by the increased uptake of glucose by the tissues elicitated with methyl salicylate and chitosan (75\% and 69\% increased WA) than non-elicitated plants.

\section{Hepatoprotective Activity}

W. somnifera root extracts showed protective role by reversing the liver marker enzymes to normal in bromobenzene induced oxidative stress model (Vedi et al., 2014). WA has been reported to prevent as well as therapeutically cure liver injury thus lowering liver inflammation and fibrosis in mice with nonalcoholic steatohepatitis (Patel et al., 2019). Jadeja et al, (2018) in his study on the effect of WA $(40 \mathrm{mg} / \mathrm{kg})$ on acetaminophen induced liver injury in mice, reported reduced hepatocytic necrosis and intrahepatic hemorrhage. The treated mice also showed reduced JNK (c-Jun N-terminal kinase pathway) activation, mitochondrial Bax (BCL2 associated X protein) translocation and nitrotyrosine generation all of which are induced by acetaminophen in untreated mice. In addition to $\mathrm{NFkB}$ activation and vimentin inhibition, the role of WA in altering the expression of LOXL2/ Snaill and thus reversing liver fibrosis has also been studied (Sayed et al., 2019). WA was also found effective in the inhibition of hepatocellular carcinoma via growth inhibition and autophagy (Siddharth et al., 2019). WA, being cytotoxic compound is also toxic to normal cells. So in order to selectively chemosensitize the cancer cells to WA, a new strategy of fortifying the crude extracts of Ashwagandha with WA was found to give better results (Sharma et al., 2011).

\section{Neuroprotective Activity}

The abnormal accumulation of amyloid $\beta$ is the main reason underlying the pathogenesis in neurodegenerative diseases like alzheimer. This abnormal secretion of amyloid $\beta$ is induced by a neurotoxic protein Tat and drug cocaine. Studies on SHAPP (Amyloid precursor protein -APP plasmid transfected SY5Y cells) cells revealed that WA is an potent inhibitor of Tat and cocaine induced amyloid $\beta$ levels and preventing neurotoxicity (Tiwari et al., 2018). The MTT assays on the Human neuroblastoma (IMR32) and Rat glioblastoma (C6) treated with alcoholic and water extracts of leaves has showed an increase in the viability of the cells by 20-30\% compared to untreated controls. The oxidative and DNA damage stress caused by $\mathrm{H}_{2} \mathrm{O}_{2}$ were also recovered in leaf extract treated cells (Shah et al., 2015). Withaferin A also showed a graudual increase in the expression levels of the neurotropic genes BDNF (Brain derived neurotrophic factor) and GDNF (Glial cell line derived neurotrophic factor) and a suppression in the mRNA expression of the neurite outgrowth inhibitory genes Nogo-a and Rho A compared to untreated SCI mice. Further WA in addition to down regulation of the pro- apoptotic protein bax also upregulates the anti- apoptotic protein bcl-2 thus reducing the apoptotic cells which would otherwise be enhanced in SCI induced mice models. Thus reporting a obvious difference in the neurobehavior in Spinal cord injury (SCI) model mice treated with WA. The administration of WA also attenuated the inflammatory response by suppressing the production of IL-lb and TNF-a (Yan et al., 2017).

Ashwamax, a commercially available root extract of W. somnifera was tracked orally using bioluminescence imaging in orthotopic murine models with glioblastoma. WA is reported to effectively inhibit the growth of glioma cell lines (Chang et al., 2016). The effect of WA on neuroglial cells was studied in vitro using C6 glioma cells and the IC50 value was reported as $355 \mu \mathrm{g} / \mathrm{ml}$, $230 \mu \mathrm{g} / \mathrm{ml}$ and $150 \mu \mathrm{g} / \mathrm{ml}$ for $24 \mathrm{hr}, 48 \mathrm{hr}$ and $72 \mathrm{hr}$ respectively. Further MTT assay deduced a significant reduction in C6 glioma cell count upon WA treatment thus proving its antiproliferating capability in a time dependent manner. Increased DNA fragmentation was also observed in C6 cells along with increase in WA concentration with maximum fragmentation at $500 \mu \mathrm{g} / \mathrm{ml}$. Further analysis on normal and C6 cells revealed that WA triggers apoptosis in cancer cells only and not in healthy cells (Hou et al., 2017)

Chang et al (2017) reported the synergistic inhibition of Glial cell proliferation by WA and Tumor treating fields (TTF). $\mathrm{TTF}$ is a novel approach which forces the actin filaments to align along the electric field lines thus interrupting the functionality of mitotic spindle in dividing cells. A study by Chang et al. (2016) provides a statistical evidence of reduction in Glioblastoma by $55 \%$ when WA was used in combination with TTFs which showed $25 \%$ recovery when used alone.

\section{Anti- cancer}

Cancer, being a formidable health challenge is the second leading cause of mortality. Though a wide variety of anti-cancer drugs have been developed, the global incidence of various cancers, and the mortality thereof, is still increasing. The number of cancer deaths is asssumed to increase by two-fold in the next 50 years (Mann et al., 2005). Since the growth and development of tumors are triggered by oxidative stress and chronic inflammation, phytochemicals with anti-oxidative and anti-inflammatory properties are thought to play important roles in the prevention and/or treatment of cancer. Different parts of the medicinal plant W. somnifera are used in a variety of traditional ayurvedic formulations. As per research, daily administration of Withania root reduced proliferation of tumour cells in methyl nitrosourea-induced (similar to estrogen receptor positive cancer model) rat mammary tumorigenesis (Khazal et al., 2013). These anticancer properties of withania are attributable to withanolides, a class of bioactive constituents isolated from W. somnifera. Several withanolide compounds isolated from various Withania species have shown antitumour activity (Mathur et al., 2006). W. somnifera hydroalcoholic 
extracts have reduced the tumour incidence and its volume in methylcholanthrene induced fibrosarcoma in mice. The treated mice also showed significant changes in the liver biochemical parameters compared to the control mice (Prakash et al., 2001). WA is an effective anticancer molecule widely used for the treatment of wide range of cancers. It works by inducing apoptosis in cancerous cells via the generation of ROS and suppression of Bcl-2 (Mayola et al., 2011). Since the last two decades, WA is being reported to poses tremendous cytotoxic activity suggesting its potential as an anti-cancer agent (Dutta et al., 2019). The docking efficiency of WA against four target proteins mortalin, p 53, p 21 and Nrf2 were studied by Vaishnavi et al. (2012) who reported that WA binds strongly to these target proteins and hence is considered as a strong cytotoxic agent. The in silico studies for understanding the molecular insights into the process of senescence induced by WA was reported by Bhargava et al. (2019). This study revealed the nuclear translocation of Nuclear factor kappa B (NFкB) and a Mitogen activated protein kinase (p38 MAPK) activation selectively in the cancer cells. This NFKB activation underlays various chronic ailments. The molecular mechanism behind the suppression of $\mathrm{NF} \kappa \mathrm{B}$ activation by WA has been elucidated using molecular dynamics simulation studies. The formation of NEMO- IKK $\beta$ complex is an essential step towards NFKB activation and its signaling pathway. The docking studies on WA revealed its potential to interact with the NFKB essential modulator (NEMO) chains to form a stearic barrier that prevents the binding of the upcoming IKK $\beta$. WA was also found to actively distrupt the existing NEMO- IKK $\beta$ complex, thus suppressing the NFKB activation (Grover et al., 2010b). WA was reported with greater binding energy towards active sites of cyclooxygenase (COX-2) than all the other phytoconstituents of W. somnifera studied using graphical software (MOLSOFT) (Prabhakaran et al., 2012).

Heat shock protein 90 (Hsp 90) is another molecular chaperone compound that serves as a target for the anti-cancer drugs. The docking efficiency of WA to distrupt the Hsp 90-Cdc37 (chaperone- cochaperone complex) supports the anti-cancer activity of WA(Grover et al., 2011b). The Structure Activity Relationship (SAR) study of WA exposed that the epoxy group at C5 (6) was responsible for the binding of withanolide to Hsp 90 and inhibit its chaperone activity. Further the hydroxyl group at $\mathrm{C} 4$ of ring $\mathrm{A}$ enhances the inhibition activity on Hsp 90. It also distrupts its interaction with Cdc37 (Hsp 90- Cdc 37) thus enhancing the anti-proliferative activity of WA (Gu et al., 2014). The SAR and ADMET(Absorption, Distribution, Metabolism, Excretion and Toxicity) studies on WA incorporated with silicon in addition to carbonyl group at $\mathrm{C} 4$ was found to enhance the activity on human epithelial ovarian carcinoma thus proving it as an essential candidate in ovarian cancer studies (Perestelo et al., 2019).The anti-tumour and radiosensitizing effects of WA was studied in Ehrlich ascites carcinoma in swiss mice and reported to be effective against tumour with a LD 50 value of approximately $80 \mathrm{mg} / \mathrm{kg}$ (Sharada et al., 1996). The effect of WA on several malignant cell lines has been assessed and it has proved to have anti-proliferative effect against acute lymphoblastic leukemia (ALL) and human myelogenous leukemia. Mandal and his coworkers (Mandal et al., 2008) explored the effect of WA on p38MAPK signaling pathways in apoptosis of leukemic cell lines and primary cells of patients with ALL.

Falkenberg et al., (2017) used Myb reporter cell line HDl 1-C3GFPl (chicken myeloid cell line with eGFP reporter gene) to screen for small molecules that inhibit Myb- dependent gene expression. His study proved withaferin A as a potent inhibitor of Myb- dependent transcription factors thus inhibiting tumorigenesis. Analysis of the mechanism of inhibition showed WA as a more potent inhibitor of $\mathrm{C} / \mathrm{EBP} \beta$ (a transcription factor cooperating with Myb in myeloid cells) than Myb by distrupting the interaction of $\mathrm{C} / \mathrm{EBP} \beta$ with its coactivator $\mathrm{p} 300$. Thus proving $\mathrm{C} / \mathrm{EBP} \beta$ as a novel target for WA action. Further molecular dynamics simulation and docking studies have proved WA as an mammalian proteosome inhibitor (Grover et al., 2010a).

Angiogenesis, the growth of new blood vessels from pre-existing vasculature, occurs in a variety of unrelated pathological conditions, such as the growth of solid tumors (Folkman et al., 1971). Vascular endothelial growth factor (VEGF) is a key signal protein that regulates angiogenesis. But the over expression of VEGF can lead to cancer. The available anti-VEGF drugs pose severe side effects in humans. Hence there is a need for some natural compound that targets VEGF. The docking studies of WA with VEGF showed favourable results highly comparable to the commercial drug Bevacizumab (Saha et al., 2013). NF-kB is a well-known transcription factor that controls gene expression of a variety of angiogenesis-related molecules (Klein et al., 2002) and mediates oxidative stress-dependent endothelial cell tube formation in collagen-I gels (Shono et al., 1996). The subsequent chloroform enriched fraction obtained from the methanolic extracts of Withania was found to pocess NF-kB inhibitory activity at an IC 50 value of $12 \mathrm{nM}$. Further the HPLC fractionation of the chloroform extract showed the WA peaks which are responsible for the inhibitory activity.

WA also showed a dose dependent activity on the expression of cyclin $\mathrm{Dl}$, a key cell cycle regulator with an $\mathrm{IC}_{50}$ value of $112 \mathrm{nM}$. In the endothelial cell sprouting assay on HUVEC (Human Umbilical Vein Endothelial Cell) cells, WA was found to inhibit cell sprouting at doses similar to that of NF-kB inhibition. It was also reported that the inhibition of NF-kB in HUVEC occurs via interference with the ubiquitin-mediated proteosome pathway. Thus WA was found to be an potent anti-angiogenic factor at doses 500 fold lower than that of its reported anti-tumour activity (Mohan et al., 2004). WA also binds to vimentin (intermediary filament protein) thus inhibiting capillary growth in corneal neovascularized mouse model (Bargagna-mohan et al., 2011).

WA has the capability to upregulate the prosurvival pathway thus effectively treating metastatic diseases. It has shown a $100 \%$ reduction in tumor growth in Uveal melanoma malignancy (Samadi et al., 2012). WA treatment has shown the suppression in growth of mouse melanoma Bl6Fl cells in vivo (Uma Devi et al., 2000) and reduce the growth of Ehrlich ascites tumor in swiss albino mice and prolong its survival by inhibiting tumor 
growth via alteration in the spindle microtubule formation (Shohat et al., 1976). WA also caused apoptosis in osteocarcoma (OS) cell lines by distruption of mitochondrial membrane potential and generation of reactive oxygen species. This compound also showed a dose-dependent inhibition of OS cell lines by triggering the caspase- 3 activation in $\mathrm{U} 2 \mathrm{OS}$ cells in a time-dependent manner with $\mathrm{IC}_{50}$ ranging from 0.32 to $7.6 \mu \mathrm{M}$. The western blot analysis revealed that WA induced cytosolic cyt-c, and PARP protein expression in addition to caspase 3 in a time-dependent manner (Li et al., 2017). The study on the effect of pure WA and lyophilized root extracts of W. somnifera on the isolated skin melanophores of frog proved its significant melanin dispersal effects in a dose dependent manner (Ali \& Meitei, 2011).

Administration of WA ( $2 \mathrm{mg} / \mathrm{kg}$ body weight) was found to inhibit the weight and volume of human colon cancer (HCT116) cells xenograft in BALB/c mice at the end of six weeks treatment. This suppression in tumour growth was also accompanied by reduced expression of Proliferating cell nuclear antigen (PCNA) in treated xenograft tumour (Choi \& Kim, 2015). Yu et al. (2011) also reported the inhibition of pancreatic cancer (Panc-1) cells xenograft tumor growth by induction of intra tumoral cell death by $30 \%$ and $58 \%$ on administration of WA at 3 and $6 \mathrm{mg} / \mathrm{kg}$ body weight, respectively. Further western blot analysis revealed that WA actually targets the heat shock protein Hsp 90 in pancreatic cell lines and inhibited its chaperone activity. Studies by Tiruveedi et al. (2018) showed around three fold decrease in serum amylase and lipase (biomarkers in acute pancreatitis) on WA treatment. The anticancer potential of WA was also found to be associated with the cell cycle arrest at the $\mathrm{G} 2 / \mathrm{M}$ phase along with the expression of apoptotic proteins in human gastric adenocarcinoma (AGS cell lines)( Kim et al., 2017).

Oral cancer is another most frequent major health problem with high mortality rate in developing countries including India. Panjamurthy et al. (2009a) studied the protective role of WA towards oral cancer. He evaluated the effect of WA on molecular pathogenesis of oral cancer by immune supression of $\mathrm{p} 53$ and bcl2 proteins. Oral administration of WA also prevented the alterations in $\mathrm{p} 53$ and bcl-2 protein expressions which are normally observed in carcinoma cells. Panjamurthy et al. (2009b) in another study on the same model reported the detoxication of the carcinogens, thus blocking their interaction with the cellular macromolecules.

The role of WA in DMBA(0.5\% 7,12-dimethylbenz(a)anthracene) induced oral squamous cell carcinoma in golden Syrian hamsters reported the decrease in $\mathrm{Na}+\mathrm{K}+$ ATPase activity and Sodium level along with increase in potassium level of tumour bearing hamsters which is probably due to increased lipid peroxidation and red cell fragility (Manoharan et al., 2009). Whereas, oral administration of WA was found to restore $\mathrm{Na}+\mathrm{K}+$-ATPase activity, red cell fragility and levels of membrane TBARS thus preventing membrane abnormalities in Oral carcinogenesis.

Breast cancer, the most common form of cancer in women is a heterogenous disorder broadly classified into different types each with a distinct gene expression signature (Perou et al., 2000). Though most of the cancer treatments target the primary tumour, the major cause of death in all the tumour types is metastatic disease. Metastatic cells are difficult to detect, highly aggressive, chemoresistant and experimentally difficult to model. The QSAR and ADMET studies on withanolides have revealed WA and eight other compounds to have a high activity against the $\mathrm{Sk}-\mathrm{Br}-3$ cells. The molecular docking studies also showed higher affinity of WA to $\beta$-tubulin with a binding score of 5.4153 which is higher than the reference compounds 5-fluorouracil (5-FU) and camptothecin with a docking score of 2.5304 and 4.1837 respectively (Yadav et al., 2017). The binding of WA covalently to the surface of tubulin at Cys303 and its down regulation in MCF cells has also been reported (Antony et al., 2014). The normal mammary cell lines did not respond to WA, whereas, it decreased the viability of both MCF7 (estrogen responsive) and MDA-MB-231 (estrogen independent)cell lines (Stan et al., 2008). This decrease in viability of the cell lines by WA was through the induction of ROS mediated paraptosis via down regulation of the paraptosis inhibitor Alix/AIP-1 (Hahm et al., 2011). WA also decreased the viability of SUM159 cells and suppressed ATR(Ataxia telangiectasia and Rad3 $\square$ related protein) thus causing cell arrest at G2/M phase (Hahm et al., 2019). Further the apoptosis caused in cultured breast cancer cell lines on WA treatment was attenuated by knockdown of multi domain proapoptotic protein Bax and Bak. Generally the level of Bak protein was found to be higher in WA treated rat models. The MNU (N-methyl-N-nitrosourea) induced breast cancer rat models showed chemoprevention after WA treatment by a gradual decrease in number of tumours per animal and tumour weight (Samanta et al., 2017). The presence of pharmacological doses of WA was reported to significantly inhibit the viability of human breast cancer cells. WA has also proved to be an potent inhibitor of breast cancer stem cells (bCSC) in vitro (Kim \& Singh, 2014) and also lowered the levels of Forkhead box Q1 (FoxQl), one of the protein responsible for bCSC maintenance (Kim et al., 2016).

The recent genome sequencing studies have revealed the occurrence of a point mutation in the estrogen receptors making it resistant to tamoxifen (breast cancer drug). The molecular docking studies of WA proved its effective binding to the estrogen receptors both in the presence and absence of the mutation thus exhibiting it as an natural anti-cancer drug against breast cancer (Ali et al., 2020).

The proteomic study on mouse mammary tumor virusneu(MMTV-neu) transgenic model showed the down regulation of various glycolytic proteins on WA treatment (Hahm et al., 2013). Vimentin is a filament protein that actually is expressed in mesenchymal cells and functions in cell motility. Some epithelial cancers and tissue sarcomas that exhibit epithelial to mesenchymal transition express vimentin (Lahat et al., 2010). WA binds directly to vimentin in vitro (Bargagna-mohan et al., 2011) further in in vivo wounding migration assay, WA treated cells lacked vimentin in contrast to the untreated cells that showed vimentin extending into a polarized, actin-containing lamellipodia. Similarly time lapse imaging of vimentin by transfecting vimentin:GFP into MDA-MB 231 breast cancer 
cells and treating with WA at higher doses over shorter periods of time showed perinuclear vimentin bundling at $60 \mathrm{~min}$ followed by rapid vimentin depolymerisation beginning in the cellular periphery and moving inwards towards the nucleus and induce apoptosis. Thus proving WA has a vimentin binding region and causes depolymerisation of cellular vimentin in migrating breast cancer cells. Higher doses of WA at $4 \mathrm{mg} / \mathrm{kg}$ inhibited both metastasis and tumor growth (Thaiparambil et al., 2011).

The radiosensitizing effect of WA on the erythrocyte antioxidant in carcinoma of uterine cervix has been reported (Reshma et al., 2007). WA was reported to inhibit the growth of human breast cancer cells. WA also accelerated the accumulation of p53 (tumour suppressor protein) (Munagala et al., 2011). The WA treatment alone or in combination with cisplatin was found to reduce tumour growth and metastasis up to $80 \%$ compared to untreated mice (Kakar et al., 2014). Yang reported that the oral administration of WA caused apoptosis in prostrate cancer cells by acting on its target proteosome ( $\beta 5$ subunit) (Yang et al., 2007).

\section{BIOSYNTHESIS OF WITHAFERIN A}

Withaferin A, being the most actively studied molecule, study of its biosynthetic pathway, the genes involved in it and identifying a better genotype has always been an ultimate goal of researchers to increase its metabolite content (Gupta et al., 2011). Withanolides being 30 carbon containing triterpenoids are synthesised by the isoprenoid pathway which includes cytosolic mevalonate (MVA) and plasticidal non mevalonate pathway or methylerythritol phosphate (MEP) pathway (Figure 2) (Sabir et al., 2013). Both these pathways participate in the withanolide synthesis leading to the synthesis of isopentenyl phosphate (IPP) (Chaurasiya et al., 2012). Farnesyl diphosphate (FPP) which is formed by the head to tail condensation of IPP is the main precursor for all the other triterpenoids (Kuzuyama, 2002).

Most of the genes encoding various enzymes of withanolide pathway have been characterized (Dhar et al., 2015). Further the effect of various elicitors on these pathway genes and on metabolite production are being worked on by various groups. The various enzymes involved in withanolide synthesis are tabulated in Table 2 .

The expression analysis of these pathway genes reveal their differential expression in different tissues, chemotypes and in response to different elicitors (Agarwal et al., 2017). Further the differential expression of these genes at different ontogenic stages and its positive correlation with the withanolide accumulation in in vitro shoot and root cultures of W. somnifera has also been reported (Sabir et al., 2013). Among the genes characterized, the over expression of the key regulatory gene, Squalene synthase(SQS) was found to increase WA content in the leaves by 4-4.5 fold (Patel et al., 2015b). Further the virus induced silencing of this gene lead to a drop in withanolide synthesis thus stating its crucial role in the pathway (Singh et al., 2015). Similarly the over expression of Cycloartenol synthase (CAS) gene increased the WA content by 1.06 to 1.66 fold (Mishra et al., 2016). The FPPS gene also plays an important role in withanolide synthesis and accumulates in response to stress conditions (Gupta et al., 2011). Senthil et al (2015) has reported a strong positive correlation of Farnesyl diphosphate synthase (FPPS) and Squalene epoxidase(SE) genes towards the accumulation of WA in 45 days and 60 days old leaf cultures.

Among the plant parts, leaves were found to express higher quantities of WA. This differential accumulation of the secondary metabolites in different organs is attributed to its tissue specific regulation of synthetic genes (Pandey et al., 2017). Further the radiotracer studies using 24-methylene cholesterol as a precursor reveals the possible transportation of withanolides from leaves to the roots (Sangwan et al., 2008). In addition, the transcriptional profiles of five important pathway genes (Squalene synthase, squaleneepoxidase, cycloartenol synthase, cytochrome P450 reductase 1 and cytochrome P450 reductase 2 ) were found to show a significant difference in the root and shoot tissues which were also parallel to the metabolite accumulation with elevated gene expression and metabolite accumulation in the leaves thus indicating the de novo tissue specific synthesis of withanolides. The sequencing of the leaf and root transcriptome by Gupta et al. (2013) has also paved a way towards understanding the tissue specific synthesis of plant secondary metabolites.

This tissue specificity can be altered by altering conditions in the environment. One such factor is the presence of endophytes which has a greater potential for sustainable agriculture. Among the various chitinolytic bacterial endophytes isolated from medicinal plants, Bacillus amyloliquefaciens and Pseudomonas fluorescens, were found to influence withanolide biosynthesis as well as to render tolerance against Alternaria alternate. An upregulation of the pathway genes were also observed in the endophyte treated plants (Mishra et al., 2018). Pandey et al. (2018) isolated a total of 29 bacterial and 11 fungal endophytes from the leaves, roots and seeds of W. somnifera and studied for its efficiency in increasing biomass and metabolite production in vitro. It was observed that the nitrogen fixing endophytes associated with the roots actually upregualted the HMGR (MVA pathway), DXR and DXS (MEP pathway) genes in the roots. Whereas, in the leaves, these endophytes had no major effect on the same genes. Thus these endophytes were able to synthesis WA in the roots which were actually absent or present in trace amounts in the control roots. This might be due to the presence of different tissue specific regulatory factors in the leaves and roots. Thus the constitutive expression of the pathway genes are actually being governed by a set of another regulatory genes termed as transcription factors (TF). TF acts as regulators of all cellular and metabolic functions. They compromise nearly $7 \%$ of the coding sequence in the plant genome (Mochida et al., 2011). Nearly 3532 annotated transcripts of TFs belonging to 90 different families were obtained from the transcriptomic database for W. somnifera leaf and root tissues (Tripathi et al., 2017). The comparative analysis of these transcripts from W. somnifera revealed the absence of homologous representatives for LWDl and WUSCHEL TF (WDR gene family) in any other Solanaceae plants. The expression profiles of these two TF were also found to be tissue specific. The LWDl factor was highly expressed in the leaves than that of the root 


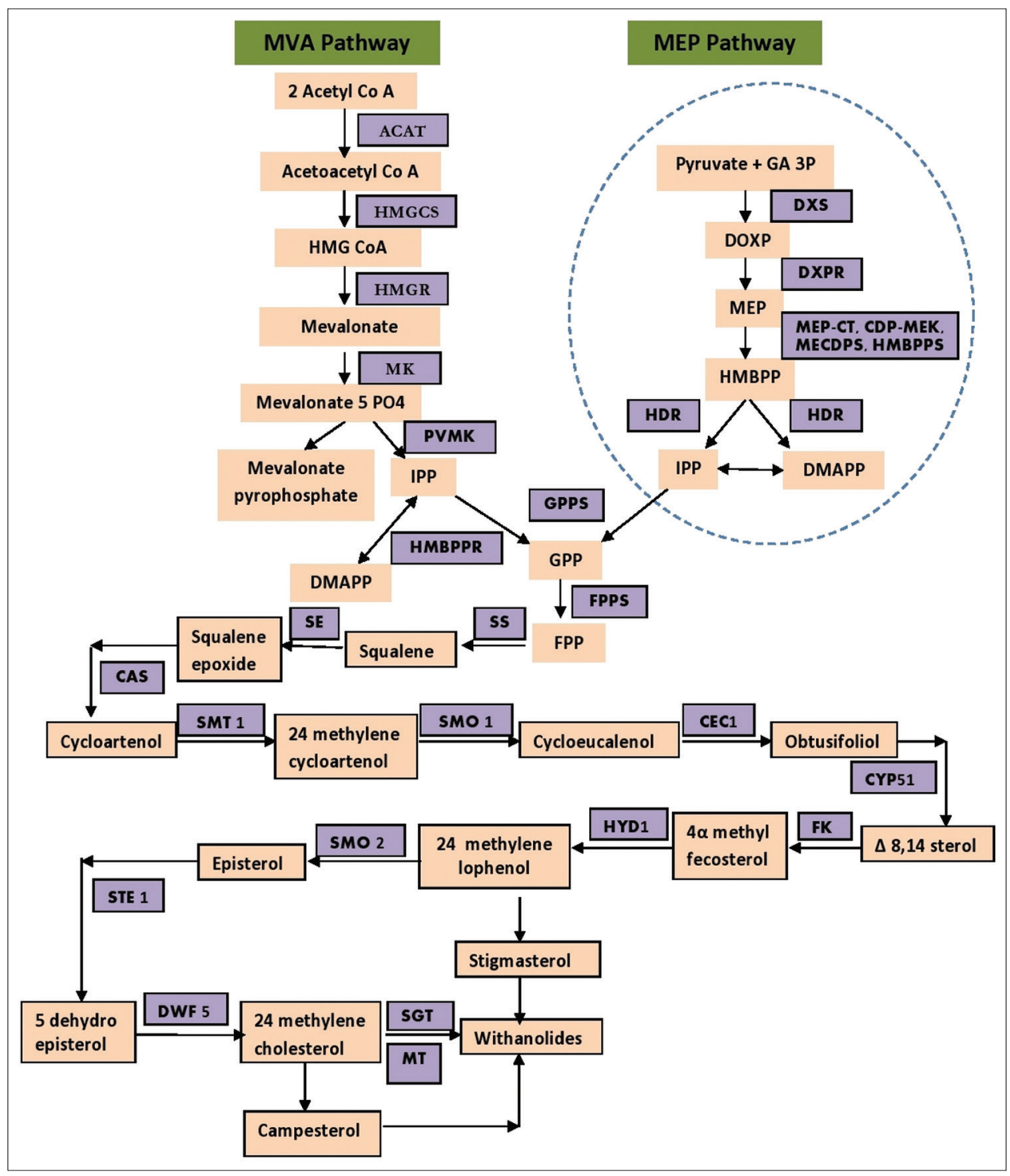

Figure 2: Withanolide Biosynthetic Pathway

whereas WUSCHEL factor was highly expressed in the roots than in the leaves. The over expression of these genes in the transformed tissues was found to be positively correlated to the WA accumulation. Several mi RNA transcriptomes influencing the regulation of withanolide biosynthesis has been identified from the root and leaf tissues of Withania somnifera. Out of the 24 and 39 miRNA families identified in the root and leaf tissues, the role of 15 and 27 miRNA families in different biological functions has been found respectively (Srivastava et al., 2018).

\section{ROLE OF PLANT TISSUE CULTURE IN WA PRODUCTION}

The complexity in the chemical synthesis of withanolides due to the stereo-chemical ring closure, occurrence of chiral centers, rigid trans-lactone groups, and high energy epoxy ring makes it economically unworkable due to minimal yields at high costs. Also the ever increasing demand of bioactive withanolides in the pharmaceutical industry is dependent on field grown plants where the plants are completely uprooted to meet the demands (Mir et al., 2014). Further the longer gestation period of 4-5 years between planting and harvesting and the effect on quality and quantity of withanolide constituents by fluxes in genotypic and environmental conditions limits the usage of field grown plants for pharmaceutical industries (Banerjee et al., 1994).

Thus, plant cell or organ culture becomes an attractive alternative to enhance the commercial prospects of withanolide production. The mass production in terms of both biomass and WA accumulation can be achieved using appropriate culture conditions when compared to the traditional plant extraction for valuable products (Mir et al., 2014). Tissue culture also proves to be a best approach for commercial propagation of endangered species of medicinal plants using various plant growth regulators in different concentrations and combinations (Baskaran et al., 2013). In vitro cultures are also used as an effective model for the study of production and accumulation of secondary metabolites due to its active growth and increased rate of 
Table 2: Role of various enzymes involved in the withanolide biosynthetic pathway

\begin{tabular}{|c|c|c|}
\hline S.No: & Enzyme & Reaction catalysed \\
\hline 1. & Acetoacetyl CoA thiolase (ACAT) & Condensation of two molecules of acetyl-CoA into aceto-acetyl CoA (Wang et al., 2017) \\
\hline 2. & HMG-CoA synthase (HMGCS) & Condensation of acetoacetyl CoA to another molecule of Acetyl CoA (Nagegowda et al., 2004) \\
\hline 3. & HMG-CoA reductase (HMGR) & Double reduction of HMG CoA to mevalonate (Benveniste, 2002) \\
\hline 4. & Mevalonate kinase (MK) & Phosphorylation of mevalonate to produce mevalonate 5-phosphate (Benveniste, 2002) \\
\hline 5. & Phosphomevalonate kinase (PVMK) & phosphorylation of mevalonate 5 -phosphate to mevalonate 5 -diphosphate (Benveniste, 2002) \\
\hline 6. & 1-deoxy-D-xylulose 5-phosphatesynthase (DXS), & Formation of Dxylulose 5phosphate (DXP) (Cordoba et al., 2011) \\
\hline 7. & DXP reductoisomerase (DXPR) & Converts DXP into MEP (Kuzuyama, 2002) \\
\hline 8. & $\begin{array}{l}\text { 2-C-methyl-D-erythritol 4-phosphate } \\
\text { cytidylyltransferase (MEP-CT) }\end{array}$ & MEP to 1-hydroxy-2-methyl-2-(E)- butenyl 4-diphosphate (Kuzuyama, 2002) \\
\hline 9. & $\begin{array}{l}\text { 4-diphosphocytidyl-2-C-methyl-D-erythritol } \\
\text { kinase (CDP-MEK) }\end{array}$ & MEP to 1-hydroxy-2-methyl-2-(E)- butenyl 4-diphosphate (Kuzuyama, 2002) \\
\hline 10. & $\begin{array}{l}\text { 2-C-methyl-D-erythritol 2,4-cyclodiphosphate } \\
\text { synthase (MECDPS) }\end{array}$ & MEP to 1-hydroxy-2-methyl-2-(E)- butenyl 4-diphosphate (Kuzuyama, 2002) \\
\hline 11. & $\begin{array}{l}\text { (E)-4-hydroxy-3-methylbut-2-enyl diphosphate } \\
\text { synthase (HMBPPS). }\end{array}$ & MEP to 1-hydroxy-2-methyl-2-(E)- butenyl 4-diphosphate (Kuzuyama, 2002) \\
\hline 12. & $\begin{array}{l}\text { 4-hydroxy-3-methyl but-2-enyl } \\
\text { diphosphatereductase (HDR) }\end{array}$ & Branching of HMBPP to IPP and DMAPP (Kuzuyama, 2002) \\
\hline 13. & Geranyl diphosphate synthase (GPPS) & Conversion of IPP to GPP (Rai et al., 2013) \\
\hline 14. & Farnesyl diphosphate synthase (FPPS) & $\begin{array}{l}\text { Head to tail condensation of isopentenyl phosphate (IPP) to farnesyl diphosphate (FPP) (Kim } \\
\text { et al., 2018) }\end{array}$ \\
\hline 15. & Squalene synthase (SS) & Reductive condensation of two molecules of FPP to squalene (Benveniste, 2002) \\
\hline 16. & Squalene epoxidase (SE) & Epoxidation of squalene to 2,3-oxidosqualene (Benveniste, 2002) \\
\hline 17. & Cycloartenol synthase (CAS) & Cyclization of 2,3-epoxysqualene to cycloartenol (Benveniste, 2002) \\
\hline 18. & Sterol- C24 methyl transferase 1 (SMT1) & Adds methyl group at C-24 position to the sterol cycloartenol (Pal et al., 2019) \\
\hline 19. & Sterol C4 methyl oxidase I (SMO 1) & Removal of methyl groups at C4 (Zhang et al., 2016) \\
\hline 20. & Sterol 14alpha-demethylase (CYP51) & Catalyses first cyclization step in sterol biosynthesis (O'Brien et al., 2005) \\
\hline 21. & $\Delta^{7}$-sterol- $C_{5}$-desaturase (STE 1) & $\begin{array}{l}\text { Catalyses formation of C- } 5 \text { double bond in the B ring of } \Delta 7 \text {-sterols to yield } \\
\Delta 5,7 \text { - sterols (Kamthan et al., 2017) }\end{array}$ \\
\hline 22. & ferase (GT) & Glycosylation of secondary plant products (Noguchi et al., 2007) \\
\hline 23. & Cytochrome $\mathrm{P} 450$ reductase (CPR) & Redox partner of multiple P450s (Bhat et al., 2014) \\
\hline
\end{tabular}

metabolism in shorter time period (Sivanandhan et al., 2011). Further tissue culture technique could also provide a means to produce disease free healthy plants for drug preparations. It also provides an continuous and controlled homogenous production of metabolites throughout the year (Gawde \& Paratkar, 2012).

The WA content in in vitro plants was reported to be higher than that of field grown plants. Study reported a 1.14 fold increase in WA content in the in vitro leaves of W. somnifera compared to the field grown leaves (Sharada et al., 1996). The withanolide content and biomass in the plant were found to be maximum at the exponential phase (7-28 days). The 28 day old plants in suspension were recorded with increased amount of Withanolides (Sivanandhan et al., 2014a). Senthil et al. (2015) has reported an maximum WA accumulation $(980 \pm 0.97 \mu \mathrm{g} / \mathrm{g}$ DW) in 45days old cultured leaves with an gradual decrease over extended period of culture. Similar synchronization with the age of cultures was found in withanolide A accumulation in root cultures.

All the in vitro cultured tissues like callus, root and shoot cultures have been investigated for WA production. Ciddi (2006) devised a method for production of WA from cell cultures of W. somnifera. The presence of WA in cell cultures was confirmed by TLC analysis and further by HPLC and ES mass spectra. An Withania spp, W. coagulans root culture was also reported to produce WA of about $11.65 \pm 2.30 \mu \mathrm{g} \mathrm{g}^{-1}$ FW (Abouzid et al., 2010). WA was also reported in the in vitro flowers $(2 \mathrm{mg} / \mathrm{g} \mathrm{DW})$ and in vitro fruits $(0.49 \mathrm{mg} / \mathrm{g}$ DW) of W. somnifera (Sivanandhan et al., 2015). Various workers described various methods for induction of callus tissue of $W$. somnifera and withanolide production from callus tissue. But callus tissues failed to synthesis withanolides, whereas multiple shoot cultures and transformed roots were able to produce withanolides. On the other hand, Chakraborty et al. (2013) has stated that the presence or absence of withanolides in any tissue type is dependent on the plant growth regulators used. In his study on callus induction and withanolide quantification using different plant growth regulators, it was surprising that callus obtained from culture media containing 2,4 D and Kinetin showed the absence of withanolide $A$ and withaferin $\mathrm{A}$, whereas the callus from media containing IBA and BAP showed the presence of both these compounds. Thus revealing the role of plant growth regulators on metabolite accumulation. In in vitro system, the production of secondary metabolites is dependent upon the media formulations, concentration of sucrose, concentration and type of Plant growth regulators (Ray \& Jha, 200la).

Plant growth regulators are significant factors that influence the growth and metabolite accumulation in plant cell cultures. Any alteration in the concentration of auxin or cytokinin or a change in their ratio would dramatically alter the growth pattern and metabolite accumulation(Rao \& Ravishankar, 2002). Among the various concentrations and combinations of plant growth regulators studied (BAP and Kn), MS medium supplemented with $4.44 \mu \mathrm{M}$ BAP was reported with 1.86 fold increase in WA content compared to control (Murugesan. et al., 2017). Similar studies on the effect of plant growth regulators reported that media supplemented with $5.0 \mu \mathrm{M}$ 6-benzyladenine (BA) 
and $1.0 \mu \mathrm{M}$ Kinetin $(\mathrm{Kn})$ yielded highest amount of WA $(13.4 \pm 1.15 \mathrm{mg} / \mathrm{g}$ of DW). This study also proved that in vitro and ex vitro shoots contained increased amount of WA in comparison to the field grown shoots whereas the root tissues which contain only a trace amount of WA did not show much variations. Also, a steady increase in WA content was observed from first to fifth week of culture (Mir et al., 2015).

The trials on different concentrations of fertilizers on fresh twigs of W. somnifera reported a fivefold increase in WA in twigs treated with DMSO compared to control (Pal et al., 2017). Ammonium sulphate treatment was reported to produce ninety fold increase in WRKYl transcription factor and an 8 fold increase in WRKY3 transcription factor. The addition of coconut milk (10\% v/v) also favoured the increased WA synthesis along with 27 fold increase in the biomass. Supplementation of coconut water along with BAP in liquid media also showed the accumulation of withanolides including WA in micro shoot cultures of W. somnifera (Ray \& Jha, 2001b). The effect of different carbon sources at different concentrations in enhancing biomass and withanolide accumulation in hairy root cultures of W. somnifera were analysed. Among various carbon sources, Sucrose is the most commonly used source because of its capability to translocate easily into the phloem of many plants. They reported a gradual enhancement in the levels of WA along with increase in glucose concentration with the highest accumulation in media containing $5 \%$ glucose. Sucrose at $4 \%$ exhibited highest WA content but sucrose at $3 \%$ equally enhanced both WA and withanolide A accumulation. Fructose at $3 \%$ alone showed trace amounts of WA. Thus this work also concludes $3 \%$ sucrose to be the best carbon source for in vitro cultures of W. somnifera (Doma et al., 2012).

The organic additives like L-glutamine (200mg/) in combination with picloram $(\mathrm{lmg} / \mathrm{l})$ and $\mathrm{KN}(0.5 \mathrm{mg} / \mathrm{l}))$ was reported to show positive effect on biomass and withanolides production (Sivanandhan et al., 2013a). Further withanolide accumulation can be enhanced by the use of elicitors or precursors. Elicitors are factors that can typically cause the cells to activate their defense system through an incompletely understood signal transduction system. Various factors like elicitor concentration, time of incubation, specificity of elicitor, culture conditions and growth stage of cultures influence the process of elicitation (Vasconsuelo \& Boland, 2007). Sivanandhan et al. (2012a) examined the use of various elicitors (Cadmium chloride, Aluminium chloride and chitosan) and precursors of withanolide synthesis (cholesterol, mevalonic acid and squalene) in suspension cultures using bioreactors and shake flask cultures. Interestingly, a decrease in biomass was observed with the use of chitosan $(100 \mathrm{mg} / \mathrm{L})$ elicitors with a 1.87 and 1.36 fold higher withanolide content in shake flask culture and bioreactors. Similar decrease in biomass and increased metabolite content upon chitosan treatment was reported by Baldi and Dixit (2008) in A. annua. The effect of biotic fungal elicitor (Piriforma indica) on biomass and WA accumulation was investigated (Ahlawat et al., 2016). Various concentrations of cell homogenate, culture filterate and culture discs were inoculated into the callus suspension cultures of W. somnifera and investigated for biomass production and WA content. A concentration of $3 \%$ for cell homogenate, culture filterate and discs were found to enhance WA accumulation at $2.04,1.78$ and 1.46 fold respectively. This elicitation was also reported to produce $11.2,8.7$ and 6.9 fold increased expression of HMG-CoA reductase (HMGR) gene among all the genes studied.

Ciddi (2006) reported the use of methyl jasmonate $(100 \mu \mathrm{M})$, salacin $(750 \mu \mathrm{M})$ and arachidonic acid $(1 \mathrm{mg} / \mathrm{l})$ as elicitors to improve production of WA. Among these salacin was found to produce 50 fold higher WA content than control. Sivanandhan et al. (2013b) also reported a 1.14-1.18 fold increase in WA accumulation in salicylic acid (SA) $(100 \mu \mathrm{M})$ treated shoots when compared to methyl jasmonate $(100 \mu \mathrm{M})$ treated shoots in liquid cultures. Further exposure of 30 days old adventitious root cultures for four days with $150 \mu \mathrm{M}$ SA showed 20 fold increase in its WA content (Sivanandhan et al., 2012b). The sterol inhibitor chlorocholinechloride was reported to inhibit WA production thus proving that precursors enter through the acetate mevalonate pathway rather than through the non mevalonate pathway. Hairy root cultures of Withania were also reported to produce WA (Banerjee et al., 1994). The effect of various biotic and abiotic stresses and their combinations on WA production from transformed callus cultures of W. somnifera has also been reported (Baldi et al., 2008). Amongst the various elicitors studied, copper sulphate $(100 \mu \mathrm{M})$ and $\mathrm{V}$. dahaliae extract $(5 \% \mathrm{v} / \mathrm{v})$ exhibited 5.4 and 9.7 fold increase in the WA production. The combination of an abiotic elicitor Copper sulphate $(100 \mu \mathrm{M})$ and the cell extract of $\mathrm{V}$. dahaliae $(5 \% \mathrm{v} / \mathrm{v})$ as a biotic elicitor showed maximum WA production. The presence of a few new proteins on copper treatment and an increase in the activities of enzymatic antioxidants in the presence of $\mathrm{Cu}$ up to $50 \mu \mathrm{M}$ followed by a gradual decrease was observed in cultures (Rout et al., 2013). The combined effect of these two elicitors showed 13.8 fold increases in WA content compared to the control thus proving the potential of dual elicitation strategy for large scale production of WA. Doma et al. (2012) also reported the elicitation activity of Chitosan, jasmonic acid, acetyl jasmonic acid and triadimefon on biomass and WA content.

Naturally occurring bioresources such as seaweeds were reported to contain amino acids, vitamins, macro and micro nutrients required for plant growth and also pocess auxin and cytokinin activity. The application of seaweed extracts has been proved beneficial in plant cultivation, improved germination and root development (Mancuso et al., 2006). Hence they also can act as an efficient biotic elicitor. Gracilaria edulis and Sargassum wightii were studied for its withanolide elicitation property in multiple shoot suspension cultures of W. somnifera and reported with 1.45-1.58 fold increase in WA accumulation when compared to control (Sivanandhan et al., 2014b).

A recent study on the effect of $\mathrm{Zn}-\mathrm{Ag}$ nanoparticles on in vitro cultures of $W$. somnifera has shown increase in activity of pathway genes involved in withanolide synthesis and carbohydrate metabolism. Among different molar ratios of $\mathrm{Zn}$ and $\mathrm{Ag}$ used for nanoparticle synthesis, the nanoparticle synthesised using 19:1 ratio of $\mathrm{Zn}$ : Ag showed maximum effect on withanolide content especially WA content in in vitro cultures of W. somnifera (Singh et al., 2019). 
Besides plant growth regulators and elicitors, the variation in physical parameters also affects the plant growth and metabolism. Light is one such very important factor that influences the metabolite production (Adil et al., 2019). The study on the effect of different light sources on WA production from callus cultures of $W$. somnifera showed a significant variation in the WA content with different light sources in the order of red $>$ green $>$ Violet $>$ yellow $>$ blue $>$ white. Red light was found to be more favorable for metabolite accumulation with two fold increase in withaferin content compared to tissues grown under white light. A reduction in biomass and increase in lipid peroxidation activity were observed in both leaf and root tissues. Further increased activities of all the enzymatic anti-oxidants were reported in both leaf and root tissues in response to UV stress with greater antioxidant activity in roots (Takshak \& Agrawal, 2014).

\section{ISOLATION AND CHARACTERIZATION OF PLANT DERIVED WITHAFERIN A}

Whole plants or plant parts are the sole components of Indian ethanomedicine. The bioactive molecules from the plants serve as the basis for synthesis of pharmaceutical drugs. Thus the isolation of active principles has become necessary for which selection of a suitable extraction procedure is required. Study on the effect of ethanol, water and ethanol-water extraction using traditional soxhlet extraction, ultrasound assisted and microwave assisted methods for different time intervals reported a variation in the level of total phenolics and total withanolides as well as DPPH and ABTS activity within different extraction methods and different solvents used (Dhanani et al., 2017).

In the case of pharmaceutical compounds, not only the extraction procedure but also the analysis method should be efficient, precise, fast and easy. Though WA is present in abundance in roots and leaves of Withania, its amount seems to vary with the geographical niche of the plants. Namdeo et al. (2011) has metabolically characterized the leaves, root and stem samples of W. somnifera from six different regions of India using H NMR spectroscopy followed by principal component analysis (PCA) and hierarchial clustering analysis (HCA). From the study it was revealed that leaf samples showed wide range of withanolides and the H NMR studies revealed the presence of two groups of withanolides:4-OH and 5,6-epoxy withanolides (WA-like steroids) and 5-OH and 6,7-epoxy withanolides (withanolide A like steroids). He also stated that the proportion of these two withanolides were a key discriminating feature of different geographical locations from where the plants were collected.

A simple yet specific and accurate high performance thin layer chromatographic (HPTLC) method for the estimation of WA using Si 60 F254 plates with Toluene: ethyl acetate: formic acid (5:5:1) as mobile phase has been developed and validated for its repeatability and accuracy (Sharma et al., 2007). This technique is being effectively used in quantification of withanolides. Further the standardization of wavelength for the quantitative scanning of WA was found to be accurate at $223 \mathrm{~nm}$ in the reflectance- absorbance mode using Scanner III(CAMAG, Switzerland) (Senthil et al., 2015). Another new rapid high performance liquid chromatography- mass spectrometry has been developed and validated for the determination of WA from mice plasma (Patil et al., 2013).

WA can be isolated from the root and leaf tissues of W. somnifera by various chromatographic techniques. A sensitive, specific, robust, validated densitometric High performance thin layer chromatographic method for the determination of WA from W. somnifera has been developed (Srtvastava et al., 2008). Keesara \& Jat (2017) extracted WA using methanol from the defatted leaf and root powders of W. somnifera. The withaferin obtained by this method was tested $90 \%$ pure by HPLC analysis. The compound was identified as WA by TLC with chloroform and methanol (9:1 ratio) as the mobile phase. The WA peak obtained was comparable to the standard peak at Rf value 0.65. An modified method HPLC-DAD for the quantification of withanolides including WA and its fingerprinting analysis has been developed and validated (Patil et al., 2010). The presence of WA from W. somnifera butanol fractions has been identified using Reverse phase preparative HPLC technique (Pramanick et al., 2008). An RP-HPLC technique for the isolation and quantification of three isomeric withanolides, WA, withanolide $\mathrm{A}$ and withanone using methanol as the mobile phase was developed using Lichrocart Purospher STAR RP-18e column (Malik et al., 2017).

\section{CONCLUSION}

Various plant derived metabolites are being consumed as a part of our regular diet and others in the form of ayurvedic formulations. Aswagandha being one such important and metabolite rich herb, is an ingredient of most of the ayurvedic preparations for various ailments. Thus, study of its important metabolites and the therapeutic role of each individual metabolite in various ailments would further support the medicinal industry. Further, a study on the measures to improve the yield in terms of metabolite content becomes an necessity. Attempts should be made to scale up the in vitro culture process to give maximum output that would be cost effective as well as safe than the traditional methods, thus aiding an improvement in the pharmaceutical industry. This review throws a flashlight onto the most important secondary metabolite WA and would therefore be helpful to the researchers to further explore and innovate methods thus paving a way for industrialization of W. somnifera.

The authors declare no conflict of interest.

\section{REFERENCES}

Abouzid, S. F., El-Bassuony, A. A., Nasib, A., Khan, S., Qureshi, J., \& Choudhary, M. I. (2010). Withaferin a production by root cultures of Withania coagulans. International Journal of Applied Research in Natural Products, 3(1), 23-27.

Adil, M., Haider Abbasi, B., \& ul Haq, I. (2019). Red light controlled callus morphogenetic patterns and secondary metabolites production in Withania somnifera L. Biotechnology Reports, 24. https://doi. org/10.1016/j.btre.2019.e00380 
Agarwal, A. V., Gupta, P., Singh, D., Dhar, Y. V., Chandra, D., \& Trivedi, P. K. (2017). Comprehensive assessment of the genes involved in withanolide biosynthesis from Withania somnifera: chemotypespecific and elicitor-responsive expression. Functional and Integrative Genomics, 17(4), 477-490. https://doi.org/10.1007/s10142-0170548-x

Ahlawat, S., Saxena, P., Ali, A., \& Abdin, M. Z. (2016). Piriformospora indica elicitation of withaferin A biosynthesis and biomass accumulation in cell suspension cultures of Withania somnifera. Symbiosis, 69, 37-46. https://doi.org/10.1007/s13199-015-0364-9

Ali, M. A., Farah, M. A., Al-Anazi, K. M., Basha, S. H., Bai, F., Lee, J., AlHemaid, F. M. A., Mahmoud, A. H., \& Hailan, W. A. Q. (2020). In silico elucidation of plausible inhibitory potential of Withaferin A of Withania somnifera medicinal herb against breast cancer targeting estrogen receptor. Current Pharmaceutical Biotechnology, 21(9), 842-851. https://doi.org/10.2174/1389201021666200129121843

Ali, S. A., \& Meitei, K. V. (2011). On the action and mechanism of withaferin-A from Withania somnifera, a novel and potent melanin dispersing agent in frog melanophores. Journal of Receptors and Signal Transduction, 31(5), 359-366. https://doi.org/10.3109/10799 893.2011.602414

Antony, M. L., Lee, J., Hahm, E. R., Kim, S. H., Marcus, A. I., Kumari, V., Ji, X., Yang, Z., Vowell, C. L., Wipf, P., Uechi, G. T., Yates, N. A., Romero, G., Sarkar, S. N., \& Singh, S. V. (2014). Growth arrest by the antitumor steroidal lactone withaferin a in human breast cancer cells is associated with down-regulation and covalent binding at cysteine 303 of $\beta$-tubulin. Journal of Biological Chemistry, 289(3), 1852-1865. https://doi.org/10.1074/jbc.M113.496844

Baldi, A., Singh, D., \& Dixit, V. K. (2008). Dual elicitation for improved production of withaferin A by cell suspension cultures of Withania somnifera. Applied Biochemistry and Biotechnology, 151(2-3), 556-564. https://doi.org/10.1007/s12010-008-8231-2

Baldi, Ashish, \& Dixit, V. K. (2008). Yield enhancement strategies for artemisinin production by suspension cultures of Artemisia annua. Bioresource Technology, 99(11), 4609-4614. https://doi.org/10.1016/j. biortech.2007.06.061

Banerjee, S., Naqvi, A. A., Mandal, S., \& Ahuja, P. S. (1994). Transformation of Withania somnifera (L) Dunal by Agrobacterium rhizogenes: Infectivity and phytochemical studies. In Phytotherapy Research, 8(8), 452-455. https://doi.org/10.1002/ptr.2650080803

Bargagna-Mohan, P., Hamza, A., Kim, Y., Khuan, Y., Ho, A., Wendschlag, N., Liu, J., Evans, R. M., Markovitz, D. M., Zhan, C., Kim, K. B., \& Mohan, R. (2011). The tumor inhibitor and antiangiogenic agent withaferin A Targets the Intermediate Filament Protein Vimentin. Chemistry \& Biology, 14(6), 623-634. https://doi.org/10.1016/j. chembiol.2007.04.010

Baskaran, P., Singh, S., \& Van Staden, J. (2013). In vitro propagation, proscillaridin A production and antibacterial activity in Drimia robusta. Plant Cell, Tissue and Organ Culture, 114(2), 259-267. https://doi. org/10.1007/s11240-013-0322-2

Batumalaie, K., Amin, M. A., Murugan, D. D., Sattar, M. Z. A., \& Abdullah, N. A. (2016). Withaferin A protects against palmitic acidinduced endothelial insulin resistance and dysfunction through suppression of oxidative stress and inflammation. Scientific Reports, 6, 1-11. https://doi.org/10.1038/srep27236

Benjumea, D., Martín-Herrera, D., Abdala, S., Gutiérrez-Luis, J., Quiñones, W., Cardona, D., Torres, F., \& Echeverri, F. (2009). Withanolides from Whitania aristata and their diuretic activity. Journal of Ethnopharmacology, 123(2), 351-355. https://doi.org/10.1016/j. jep.2008.12.014

Benveniste, P. (2002). Sterol Metabolism. The Arabidopsis Book, 1, e0004. https://doi.org/10.1199/tab.0004

Bhargava, P., Malik, V., Liu, Y., Ryu, J., Kaul, S. C., Sundar, D., \& Wadhwa, R. (2019). Molecular Insights Into Withaferin-A-Induced Senescence : Bioinformatics and Experimental Evidence to the Role of NF $\kappa \mathrm{B}$ and CARF. Journals of Gerontology, 74(2), 183-191. https://doi. org/10.1093/gerona/gly107

Bhat, W. W., Rana, S., Dhar, N., Razdan, S., Pandith, S. A., Vishwakarma, R., \& Lattoo, S. K. (2014). An inducible NADPH-cytochrome P450 reductase from Picrorhiza kurrooa - An imperative redox partner of cytochrome P450 enzymes. Functional and Integrative Genomics, 14(2), 1-19. https://doi.org/10.1007/s10142-014-0362-7

Bhattacharya, A., Ghosal, S., \& Bhattacharya, S. K. (2001). Anti-oxidant effect of Withania somnifera glycowithanolides in chronic footshock stress-induced perturbations of oxidative free radical scavenging enzymes and lipid peroxidation in rat frontal cortex and striatum. Journal of Ethnopharmacology, 74(1), 1-6. https://doi.org/10.1016/ S0378-8741(00)00309-3

Bhattacharya, S. K., Satyan, K. S., \& Ghosal, S. (1997). Antioxidant activity of glycowithanolides from Withania somnifera. Indian Journal of Experimental Biology, 74(1), 1-6.

Budhiraja, R., Krishan, P., \& Sudhir, S. (2000). Biological Activity of Withanolides. Journal of Scientific and Industrial Research, 59(11), 904-911.

Chakraborty, N., Banerjee, D., Ghosh, M., Pradhan, P., Gupta, N. S., Acharya, K., \& Banerjee, M. (2013). Influence of plant growth regulators on callus mediated regeneration and secondary metabolites synthesis in Withania somnifera (L.) Dunal. Physiology and Molecular Biology of Plants, 19, 117-125. https://doi.org/10.1007/ s12298-012-0146-2

Chandel, V., Raj, S., Rathi, B., \& Kumar, D. (2020). In silico identification of potent fda approved drugs against coronavirus covid-19 main protease: A drug repurposing approach. Chemical Biology Letters, 7(3), 166-175.

Chandrasekaran, S., Veronica, J., Gundampati, R. K., Sundar, S., \& Maurya, R. (2015). Exploring the inhibitory activity of Withaferin-A against Pteridine reductase- 1 of $\mathrm{L}$. donovani Exploring the inhibitory activity of Withaferin-A against Pteridine. Jourm Nal of Enzyme Inhibition and Medicinal Chemistry, 31(6), 1029-1037. https://doi.or $\mathrm{g} / 10.3109 / 14756366.2015 .1088841$

Chang E, Pohling C, Beygui N, Patel C, Rosenberg J, Ha DH, G. S. (2017) Synergistic Inhibition of Glioma Cell Proliferation by Withaferin A and Tumor Treating Fields. Physiology \& Behavior, 176(5), 139-148. https://doi.org/10.1016/j.physbeh.2017.03.040

Chang, E., Pohling, C., Natarajan, A., Witney, T. H., Kaur, J., Xu, L., Gowrishankar, G., D'Souza, A. L., Murty, S., Schick, S., Chen, L., Wu, N., Khaw, P., Mischel, P., Abbasi, T., Usmani, S., Mallick, P., \& Gambhir, S. S. (2016). AshwaMAX and withaferin a inhibits gliomas in cellular and murine orthotopic models. Journal of Neuro-Oncology, 126(2), 253-264. https://doi.org/10.1007/s11060-015-1972-1

Chaudhary, A., Kalra, R. S., Malik, V., Katiyar, S. P., \& Sundar, D. (2019). Withaferin-A Lacks Anti-Metastasis Potency: Bioinformatics and Experimental Evidences. Scientific Reports, 9, 1-11. https://doi. org/10.1038/s41598-019-53568-6

Chaurasiya, N. D., Sangwan, N. S., Sabir, F., Misra, L., \& Sangwan, R. S. (2012). Withanolide biosynthesis recruits both mevalonate and DOXP pathways of isoprenogenesis in Ashwagandha Withania somnifera L. (Dunal). Plant Cel/ Reports, 31(10), 1889-1897. https:// doi.org/10.1007/s00299-012-1302-4

Choi, B. Y., \& Kim, B.-W. (2015). Withaferin-A Inhibits Colon Cancer Cell Growth by Blocking STAT3 Transcriptional Activity. Journal of Cancer Prevention, 20(3), 185-192. https://doi.org/10.15430/ jcp.2015.20.3.185

Choudhary, M. I., Hussain, S., Yousuf, S., Dar, A., Mudassar, \& Atta-UrRahman. (2010). Chlorinated and diepoxy withanolides from Withania somnifera and their cytotoxic effects against human lung cancer cell line. Phytochemistry, 71, 2205-2209. https://doi.org/10.1016/j. phytochem.2010.08.019

Ciddi, V. (2006). Withaferin A from cell cultures of Withania somnifera. Indian Journal of Pharmaceutical Sciences, 68(4), 490-492. https:// doi.org/10.4103/0250-474X.27824

Cordero, C. P., Morantes, S. J., Páez, A., Rincón, J., \& Aristizábal, F. A. (2009). Cytotoxicity of withanolides isolated from Acnistus arborescens. Fitoterapia, 80(6), 364-368. https://doi.org/10.1016/j. fitote.2009.05.011

Cordoba, E., Porta, H., Arroyo, A., San Román, C., Medina, L. Rodríguez-Concepción, M., \& León, P. (2011). Functional characterization of the three genes encoding 1-deoxy-D-xylulose 5-phosphate synthase in maize. Journal of Experimental Botany, 62(6), 2023-2038. https://doi.org/10.1093/jxb/erq393

Dai, T., Zhong, G., Wang, Z., Liang, C., Pei, X., \& Dai, R. (2019). Studies on oral bioavailability and first $\square$ pass metabolism of withaferin $A$ in rats using LC - MS / MS and Q - TRAP. Biomedical Chromatography, 382, 1-14. https://doi.org/10.1002/bmc.4573

Dhanani, T., Shah, S., Gajbhive, N. A., \& Kumar, S. (2017). Effect of extraction methods on yield, phytochemical constituents and antioxidant activity of Withania somnifera. Arabian Journal of Chemistry, 10, S1193S1199. https://doi.org/10.1016/j.arabjc.2013.02.015 
Dhar, N., Razdan, S., Rana, S., Bhat, W. W., Vishwakarma, R., \& Lattoo, S. K. (2015). A decade of molecular understanding of withanolide biosynthesis and in vitro studies in Withania somnifera(L.) dunal: Prospects and perspectives for pathway engineering. Frontiers in Plant Science, 6, 1-20. https://doi.org/10.3389/fpls.2015.01031

Doma, M., Abhayankar, G., Reddy, V. D., \& Kavi Kishor, P. B. (2012). Carbohydrate and elicitor enhanced withanolide (withaferin a and withanolide A) accumulation in hairy root cultures of Withania somnifera (L.). Indian Journal of Experimental Biology, 50(7), 484-490.

Dutta, K., Patel, P., \& Julien, J. P. (2018). Protective effects of Withania somnifera extract in SOD1 G93A mouse model of amyotrophic lateral sclerosis. Experimental Neurology, 309(July), 193-204. https://doi. org/10.1016/j.expneurol.2018.08.008

Dutta, R., Khalil, R., Green, R., Mohapatra, S. S., \& Mohapatra, S. (2019). Withania somnifera ( Ashwagandha) and Withaferin A : Potential in Integrative Oncology. International Journal of Molecular Sciences, $20,1-19$.

Falkenberg, K. D., Jakobs, A., Matern, J. C., Dörner, W., Uttarkar, S., Trentmann, A., Steinmann, S., Coulibaly, A., Schomburg, C., Mootz, H. D., Schmidt, T. J., \& Klempnauer, K. H. (2017). Withaferin A, a natural compound with anti-tumor activity, is a potent inhibitor of transcription factor C/EBP $\beta$. Biochimica et Biophysica Acta-Molecular Cel/ Research, 1864(7), 1349-1358. https://doi.org/10.1016/j. bbamcr.2017.05.003

Folkman, J., Merler, E., Abernathy, C., \& Williams, G. (1971). Isolation of a tumor factor responsible for angiogenesis. Journal of Experimental Medicine, 133(2), 275-288. https://doi.org/10.1084/jem.133.2.275

Fuska, J., Fuskova, A., Rosazza, J. P., \& Nicholas, A. W. (1984). Novel cytotoxic and antitumor agents. IV. Withaferin A: Relation of its structure to the in vitro cytotoxic effects on P388 cells. Neoplasma, $31(1), 31-36$

Gawde, A. J., \& Paratkar, G. T. (2012). Production and enhancement of wedelolactone in shoot cultures of eclipta alba. Journal of Herbs, Spices and Medicinal Plants, 18(2), 203-209. https://doi.org/10.108 0/10496475.2010.499305

Grover, A., Agrawal, V., Shandilya, A., Bisaria, V. S., \& Sundar, D. (2011a). Non-nucleosidic inhibition of Herpes simplex virus DNA polymerase : mechanistic insights into the anti-herpetic mode of action of herbal drug withaferin A. BMC Bioinformatics, 12(Suppl 13), S22. https:// doi.org/10.1186/1471-2105-12-S13-S22

Grover, A., Katiyar, S. P., Jeyakanthan, J., Dubey, V. K., \& Sundar, D. (2012). Blocking Protein kinase $\mathrm{C}$ signaling pathway : mechanistic insights into the anti-leishmanial activity of prospective herbal drugs from Withania somnifera. BMC Genomics, 13(Suppl 7), S20. https://doi. org/10.1186/1471-2164-13-S7-S20

Grover, A., Shandilya, A., Agrawal, V., Pratik, P., Bhasme, D., Bisaria, V. S., \& Sundar, D. (2011b). Hsp90/Cdc37 Chaperone/co-chaperone complex, a novel junction anticancer target elucidated by the mode of action of herbal drug Withaferin A. BMC Bioinformatics, 12(Suppl 1), S30. https://doi.org/10.1186/1471-2105-12-S1-S30

Grover, A., Shandilya, A., Bisaria, V. S., \& Sundar, D. (2010a). Probing the anticancer mechanism of prospective herbal drug Withaferin $A$ on mammals: A case study on human and bovine proteasomes. BMC Genomics, 11(SUPPL. 4), S15. https://doi.org/10.1186/1471-216411-S4-S15

Grover, A., Shandilya, A., Punetha, A., Bisaria, V. S., \& Sundar, D. (2010b). Inhibition of the NEMO/IKK $\beta$ association complex formation, a novel mechanism associated with the NF-KB activation suppression by Withania somnifera's key metabolite withaferin A. BMC Genomics, 11(SUPPL. 4), S25. https://doi.org/10.1186/1471-2164-11-S4-S25

Gu, M., Yu, Y., Gunaherath, G. M. K. B., Gunatilaka, A. A. L., Li, D., \& Sun, D. (2014). Structure-activity relationship (SAR) of withanolides to inhibit Hsp90 for its activity in pancreatic cancer cells. Investigational New Drugs, 32(1), 68-74. https://doi.org/10.1007/s10637-013-9987-y

Guo, R., Gan, L., Lau, W. B., Yan, Z., Xie, D., Gao, E., Christopher, T. A., Lopez, B. L., Ma, X., \& Wang, Y. (2019). Withaferin a prevents myocardial ischemia/reperfusion injury by upregulating AMPactivated protein kinase-dependent B-cell lymphoma2 signaling. Circulation Journal, 83(8), 1726-1736. https://doi.org/10.1253/circj. CJ-18-1391

Gupta, P., Akhtar, N., Tewari, S. K., Sangwan, R. S., \& Trivedi, P. K. (2011). Differential expression of farnesyl diphosphate synthase gene from Withania somnifera in different chemotypes and in response to elicitors. Plant Growth Regulation, 65(1), 93-100. https://doi. org/10.1007/s10725-011-9578-x

Gupta, P., Goel, R., Pathak, S., Srivastava, A., Singh, S. P., Sangwan, R. S. Asif, M. H., \& Trivedi, P. K. (2013). De Novo Assembly, Functional Annotation and Comparative Analysis of Withania somnifera Leaf and Root Transcriptomes to Identify Putative Genes Involved in the Withanolides Biosynthesis. PLoS One, 8(5), e62714. https://doi. org/10.1371/journal.pone.0062714

Hahm, E. R., Lee, J., Kim, S. H., Sehrawat, A., Arlotti, J. A., Shiva, S. S. Bhargava, R., \& Singh, S. V. (2013). Metabolic alterations in mammary cancer prevention by withaferin A in a clinically relevant mouse model. Journal of the National Cancer Institute, 105(15), 1111-1122. https:// doi.org/10.1093/jnci/djt153

Hahm, E. R., Lee, J., \& Singh, S. V. (2019). Withaferin A inhibits expression of ataxia telangiectasia and Rad3 - related kinase and enhances sensitivity of human breast cancer cells to cisplatin. Molecular Carcinogenesis, 58(11), 2139-2148. https://doi.org/10.1002/ mc.23104

Hahm, E. R., Moura, M. B., Kelley, E. E., van Houten, B., Shiva, S., \& Singh, S. V. (2011). Withaferin a-induced apoptosis in human breast cancer cells is mediated by reactive oxygen species. PLOS ONE, 6(8). https://doi.org/10.1371/journal.pone.0023354

Hou, W. C., Miao, X. H., Ma, L. J., Bai, X. X., Liu, Q., \& Song, L. (2017). Withaferin a Induces Apoptosis in Rat C6 Glioma Cells Through Regulating Nf-Kb Nuclear Translocation and Activation of Caspase Cascade. African Journal of Traditional, Complementary, and Alternative Medicines, 14(2), 319-324. https://doi.org/10.21010/ ajtcam.v14i2.33

Hsu, J. H., Chang, P. M., Cheng, T., Kuo, Y., Wu, A. T., Tran, T., Yang, Y., \& Chen, J. (2019). Identification of Withaferin A as a Potential. Cancers, $11,1-18$.

Jadeja, R. N., Urrunaga, N. H., Dash, S., Khurana, S., Saxena, N. K., \& Regents, G. (2018). Withaferin A reduces acetaminophen induced liver injury in mice. Biochem Pharmacol. , 97(1), 706-721. https://doi. org/10.1016/j.bcp.2015.07.024

Jonathan, G., Rivka, R., Avinoam, S., Lumír, H., \& Nirit, B. (2015). Hypoglycemic activity of withanolides and elicitated Withania somnifera. Phytochemistry, 116(1), 283-289. https://doi.org/10.1016/j. phytochem.2015.02.029

Kakar, S. S., Ratajczak, M. Z., Powell, K. S., Moghadamfalahi, M., Miller, D. M., Batra, S. K., \& Singh, S. K. (2014). Withaferin a alone and in combination with cisplatin suppresses growth and metastasis of ovarian cancer by targeting putative cancer stem cells. PLOS ONE, 9(9). https://doi.org/10.1371/journal.pone.0107596

Kamthan, A., Kamthan, M., \& Datta, A. (2017). Expression of C-5 sterol desaturase from an edible mushroom in fisson yeast enhances its ethanol and thermotolerance. PLoS ONE, 12(3), 1-20. https://doi. org/10.1371/journal.pone.0173381

Keesara, B. R., \& Jat, R. K. (2017). Isolation and characterization of withaferin-a from the Withania somnifera (ashwagandha). Journal of Drug Delivery and Therapeutics, 7(1), 65-69. https://doi.org/10.22270/ jddt.v7i1.1375

Khazal, K. F., Samuel, T., Hill, D. L., \& Grubbs, C. J. (2013). Effect of an extract of Withania somnifera root on estrogen receptor-positive mammary carcinomas. Anticancer Research, 33(4), 1519-1524.

Khedgikar, V., Kushwaha, P., Gautam, J., Verma, A., Changkija, B., Kumar, A., Sharma, S., Nagar, G. K., Singh, D., Trivedi, P. K., Sangwan, N. S., Mishra, P. R., \& Trivedi, R. (2013). Withaferin A: A proteasomal inhibitor promotes healing after injury and exerts anabolic effect on osteoporotic bone. Ce/l Death and Disease, 4(8), e778-17. https:// doi.org/10.1038/cddis.2013.294

Kim, G., Kim, T. H., Hwang, E. H., Chang, K. T., Hong, J. J., \& Park, J. H. (2017). Withaferin a inhibits the proliferation of gastric cancer cells by inducing G2/M cell cycle arrest and apoptosis. Oncology Letters, 14(1), 416-422. https://doi.org/10.3892/ol.2017.6169

Kim, H. Y., Kim, D. K., Bae, S. H., Gwak, H. R., Jeon, J. H., Kim, J K., Lee, B. II, You, H. J., Shin, D. H., Kim, Y. H., Kim, S. Y., Han, S. S., Shim, J. K. Lee, J. H., Kang, S. G., \& Jang, H. (2018). Farnesyl diphosphate synthase is important for the maintenance of glioblastoma stemness. Experimental and Molecular Medicine, 50(10), 1-12. https://doi. org/10.1038/s12276-018-0166-2

Kim, S. H., Kaschula, C. H., Priedigkeit, N., Lee, A. V., \& Singh, S. V. (2016). Forkhead box Q1 is a novel target of breast cancer stem cell inhibition by diallyl trisulfide. Journal of Biological Chemistry, 291(26), 13495-13508. https://doi.org/10.1074/jbc.M116.715219 
Kim, S. H., \& Singh, S. V. (2014). Mammary cancer chemoprevention by withaferin $A$ is accompanied by in vivo suppression of self-renewal of cancer stem cells. Cancer Prevention Research, 7(7), 738-747. https://doi.org/10.1158/1940-6207.CAPR-13-0445

Klein, S., de Fougerolles, A. R., Blaikie, P., Khan, L., Pepe, A., Green, C. D., Koteliansky, V., \& Giancotti, F. G. (2002). 51 Integrin Activates an NF- B-Dependent Program of Gene Expression Important for Angiogenesis and Inflammation. Molecular and Cellular Biology, 22(16), 5912-5922. https://doi.org/10.1128/mcb.22.16.59125922.2002

Kotagale, N. R., Kedia, A., Gite, R., Rahmatkar, S. N., Gawande, D. Y., Umekar, M. J., Taksande, B. G., Kedia, A., Nilkanth, S., Yugraj, D., Janraoji, M., \& Gulabrao, B. (2018). Withaferin A attenuates Alcohol Abstinence Signs in Rats. Pharmacognasy Journal, 10(6), 1190-1195.

Ku, S. K., \& Bae, J. S. (2014a). Antiplatelet, anticoagulant, and profibrinolytic activities of withaferin A. Vascular Pharmacology, 60(3), 120-126. https://doi.org/10.1016/j.vph.2014.01.009

Ku, S. K., Han, M. S., \& Bae, J. S. (2014b). Withaferin A is an inhibitor of endothelial protein $\mathrm{C}$ receptor shedding in vitro and in vivo. Food and Chemical Toxicology, 68, 23-29. https://doi.org/10.1016/j. fct.2014.03.009

Kumar, S., Jena, L., Sahoo, M., Kakde, M., Daf, S., \& Varma, A. K. (2015). In Silico Docking to Explicate Interface between plant originated inhibitors and E6 oncogenic protein of highly threatening Human Papilloma Virus. Genomics and Informatics, 13(2), 60-67.

Kumari, M., \& Gupta, R. P. (2015). In vitro antibacterial effect of Withania somnifera root extract on Escherichia coli. Veterinary World, 8(1), 57-60. https://doi.org/10.14202/vetworld.2015.57-60

Kuzuyama, T. (2002). Mevalonate and nonmevalonate pathways for the biosynthesis of isoprene units. Bioscience, Biotechnology and Biochemistry, 66(8), 1619-1627. https://doi.org/10.1271/bbb.66.1619

Lahat, G., Zhu, Q. S., Huang, K. L., Wang, S., Bolshakov, S., Liu, J., Torres, K., Langley, R. R., Lazar, A. J., Hung, M. C., \& Lev, D. (2010). Vimentin is a novel anti-cancer therapeutic target; insights from In Vitro and In Vivo mice xenograft studies. In PLoS ONE (p. e10105). https://doi. org/10.1371/journal.pone.0010105

Lavie, D., Glotter, E., \& Shvo, Y. (1965a). 1371. Constituents of Withania somnifera Dun. Part IV. The structure of withaferin A. Journal of the Chemical Society (Resumed), 7517-7531. https://doi.org/10.1039/ JR9650007517

Lavie, D., Glotter, E., \& Shvo, Y. (1965b). Constituents of Withania somnifera Dun. III. The Side Chain of Withaferin A. Journal of Organic Chemistry, 30(6), 1774-1778. https://doi.org/10.1021/jo01017a015

Li, A. X., Sun, M., \& Li, X. (2017). Withaferin-A induces apoptosis by activating p 38 mitogen activated protei kinase signalling cascade in. European Review for Medical and Pharmacological Sciences, 21(6), 1368-1374.

Malik, M. Y., Taneja, I., Siva, K., Raju, R., Gayen, J. R., Singh, S. P., Sangwand, N. S., \& Wahajuddin, M. (2017). RP-HPLC Separation of Isomeric Withanolides: Method Development, Validation and Application to In situ Rat Permeability Determination. J Chromatogr Sci., 55(7), 729-735. https://doi.org/10.1093/chromsci/bmx027

Mancuso, S., Azzarello, E., Mugnai, S., \& Briand, X. (2006). Marine bioactive substances (IPA extract) improve foliar ion uptake and water stress tolerance in potted Vitis vinifera plants. Advances in Horticultural Science, 20(2), 156-161. https://doi.org/10.1400/53262

Mandal, C., Dutta, A., Mallick, A., Chandra, S., Misra, L., Sangwan, R. S., \& Mandal, C. (2008). Withaferin A induces apoptosis by activating p38 mitogen-activated protein kinase signaling cascade in leukemic cells of lymphoid and myeloid origin through mitochondrial death cascade. Apoptosis, 13(12), 1450-1464. https://doi.org/10.1007/ s10495-008-0271-0

Mandal, P., Ghosal, M., Misra, T. K., \& Das, A. P. (2010). Pharmacognostic and free-radical scavenging activity in the different parts of ashwagandha [Withania somnifera (L. Dunal)]. International Journal of Drug Development and Research, 2(4), 830-843.

Mann, J. R., Backlund, M. G., \& DuBois, R. N. (2005). Mechanisms of disease: Inflammatory mediators and cancer prevention. Nature Clinical Practice Oncology, 2(4), 202-210. https://doi.org/10.1038/ncponc0140

Mathur, R., Gupta, S. K., Singh, N., Mathur, S., Kochupillai, V., \& Velpandian, T. (2006). Evaluation of the effect of Withania somnifera root extracts on cell cycle and angiogenesis. Journal of Ethnopharmacology, 105(3), 336-341. https://doi.org/10.1016/j.jep.2005.11.020

Matsuda, H., Murakami, T., Kishi, A., \& Yoshikawa, M. (2001). Structures of withanosides I, II, III, IV, V, VI, and VII, new withanolide glycosides, from the roots of Indian Withania somnifera DUNAL. and inhibitory activity for tachyphylaxis to clonidine in isolated guinea-pig ileum. Bioorganic and Medicinal Chemistry, 9(6), 1499-1507. https://doi. org/10.1016/S0968-0896(01)00024-4

Mayola, E., Gallerne, C., Esposti, D. D., Martel, C., Pervaiz, S., Larue, L. Debuire, B., Lemoine, A., Brenner, C., \& Lemaire, C. (2011). Withaferin A induces apoptosis in human melanoma cells through generation of reactive oxygen species and down-regulation of $\mathrm{Bcl}-2$. Apoptosis, 16(10), 1014-1027. https://doi.org/10.1007/s10495-011-0625-x

Mir, B. A., Khazir, J., Hakeem, K. R., Koul, S., \& Cowan, D. A. (2015). Enhanced production of withaferin-A in shoot cultures of Withania somnifera (L) Dunal. Journal of Plant Biochemistry and Biotechnology, 23(4), 430-434. https://doi.org/10.1007/s13562-014-0264-8

Mir, B. A., Mir, S. A., \& Koul, S. (2014). In vitro propagation and withaferin A production in Withania ashwagandha, a rare medicinal plant of India. Physiology and Molecular Biology of Plants, 20(3), 357-364. https:// doi.org/10.1007/s12298-014-0243-5

Mishra, A., Singh, S. P., Mahfooz, S., Bhattacharya, A., Mishra, N. Shirke, P. A., \& Nautiyal, C. S. (2018). Bacterial endophytes modulates the withanolide biosynthetic pathway and physiological performance in Withania somnifera under biotic stress. Microbiological Research, 212-213(October), 17-28. https://doi.org/10.1016/j. micres.2018.04.006

Mishra, L. C., Singh, B. B., \& Dagenais, S. (2000). Scientific basis for the therapeutic use of Withania somnifera (ashwagandha): A review. In Alternative Medicine Review (pp. 334-346).

Mishra, S., Bansal, S., Mishra, B., Sangwan, R. S., Asha, Jadaun, J. S., \& Sangwan, N. S. (2016). RNAi and homologous over-expression based functional approaches reveal triterpenoid synthase gene-cycloartenol synthase is involved in downstream withanolide biosynthesis in Withania somnifera. PLoS ONE. https://doi.org/10.1371/journal. pone.0149691

Mochida, K., Yoshida, T., Sakurai, T., Yamaguchi-Shinozaki, K., Shinozaki, K., \& Tran, L. S. P. (2011). In silico analysis of transcription factor repertoires and prediction of stress-responsive transcription factors from six major gramineae plants. DNA Research, 18(5), 321-332. https://doi.org/10.1093/dnares/dsr019

Mohan, R., Hammers, H., Bargagna-Mohan, P., Zhan, X., Herbstritt, C., Ruiz, A., Zhang, L., Hanson, A., Conner, B., Rougas, J., \& Pribluda, V. (2004). Withaferin A is a potent inhibitor of angiogenesis. Angiogenesis, 7(2), 115-122. https://doi.org/10.1007/s10456-004-1026-3

Munagala, R., Kausar, H., Munjal, C., \& Gupta, R. C. (2011). Withaferin a induces p53-dependent apoptosis by repression of HPV oncogenes and upregulation of tumor suppressor proteins in human cervical cancer cells. Carcinogenesis, 32(11), 1697-1705. https://doi. org/10.1093/carcin/bgr192

Murugan S., Ameesh M, Deepapriya, Kalpana R, G. G., \& Professor, A. (2015). A Study on the efficacy of Withaferin-A in reducing oxidative stress against DEN induced hepatocellular carcinoma. IOSR Journal of Dental and Medica/ Sciences Ver. //, 14(9), 2279-2861. https://doi. org/10.9790/0853-14922331

Murugesan., P., Laras, E.,Joni, K., Valizadeh, M., \& Senthil, K. (2017). A study on the influence of plant growth regulator on shoot multiplication and evaluation of major withanolides in withania somnifera. World Journal of Pharmacy and Pharmaceutical Sciences, August 2017. 842-853. https://doi.org/10.20959/wjpps20178-8944

Nagegowda, D. A., Bach, T. J., \& Chye, M. L. (2004). Brassica juncea 3-hydroxy-3-methylglutaryl (HMG)-CoA synthase 1: Expression and characterization of recombinant wild-type and mutant enzymes. Biochemical Journal, 383(3), 517-527. https://doi.org/10.1042/ BJ20040721

Namdeo, A. G., Sharma, A., Yadav, K. N., Gawande, R., Mahadik, K. R., Lopez-Gresa, M. P., Kim, H. K., Choi, Y. H., \& Verpoorte, R. (2011) Metabolic characterization of withania somnifera from different regions of India using NMR spectroscopy. Planta Medica, 77(17), 1958-1964. https://doi.org/10.1055/s-0031-1279997

Nefzi, A., \& Ben Abdallah, R. A. (2016). Antifungal activity of aqueous and organic extracts from Withania somnifera L. against Fusarium oxysporum f. sp. radicis-lycopersici. Journal of Microbial \& Biochemical Technology, 8(3), 144-150. https://doi.org/10.4172/19485948.1000277

Noguchi, A., Saito, A., Homma, Y., Nakao, M., Sasaki, N., Nishino, T., Takahashi, S., \& Nakayama, T. (2007). A UDP-glucose:Isoflavone 
7-O-glucosyltransferase from the roots of soybean (Glycine max) seedlings: Purification, gene cloning, phylogenetics, and an implication for an alternative strategy of enzyme catalysis. Journal of Biological Chemistry, 282(32), 23581-23590. https://doi.org/10.1074/ jbc.M702651200

O'Brien, M., Chantha, S. C., Rahier, A., \& Matton, D. P. (2005). Lipid signaling in plants. Cloning and expression analysis of the obtusifoliol $14 \alpha$-demethylase from Solanum chacoense Bitt., a pollination- and fertilization-induced gene with both obtusifoliol and lanosterol demethylase activity. Plant Physiology, 139(2), 734-749. https://doi. org/10.1104/pp.105.066639

Oh, J. H., Lee, T. J., Park, J. W., \& Kwon, T. K. (2008). Withaferin A inhibits iNOS expression and nitric oxide production by Akt inactivation and down-regulating LPS-induced activity of NF-кB in RAW 264.7 cells. European Journal of Pharmacology, 599(1-3), 11-17. https://doi. org/10.1016/j.ejphar.2008.09.017

Pal, S., Rastogi, S., Nagegowda, D. A., Gupta, M. M., Shasany, A. K., \& Chanotiya, C. S. (2019). RNAi of Sterol Methyl Transferase1 Reveals its Direct Role in Diverting Intermediates Towards Withanolide/ Phytosterol Biosynthesis in Withania somnifera. Plant and Cell Physiology, 60(3), 672-686. https://doi.org/10.1093/pcp/pcy237

Pal, S., Yadav, A. K., Singh, A. K., Rastogi, S., Gupta, M. M., Verma, R. K., Nagegowda, D. A., Pal, A., \& Shasany, A. K. (2017). Nitrogen treatment enhances sterols and withaferin A through transcriptional activation of jasmonate pathway, WRKY transcription factors, and biosynthesis genes in Withania somnifera (L.) Dunal. Protoplasma, 254(1), 389-399. https://doi.org/10.1007/s00709-016-0959-x

Pandey, S. S., Singh, S., Pandey, H., Srivastava, M., Ray, T., Soni, S., Pandey, A., Shanker, K., Babu, C. S. V., Banerjee, S., Gupta, M. M., \& Kalra, A. (2018). Endophytes of Withania somnifera modulate in planta content and the site of withanolide biosynthesis. Scientific Reports, 8(1), 1-19. https://doi.org/10.1038/s41598-018-23716-5

Pandey, V., Ansari, W. A., Misra, P., \& Atri, N. (2017). Withania somnifera: Advances and implementation of molecular and tissue culture techniques to enhance its application. In Frontiers in Plant Science (p. 1390). https://doi.org/10.3389/fpls.2017.01390

Pandit, M. (n.d.). In silico studies reveal potential antiviral activity of phytochemicals from medicinal plants for the treatment of COVID-19 infection. 1-38. https://doi.org/10.21203/rs.3.rs-22687/v1

Panjamurthy, K., Manoharan, S., Balakrishnan, S., Suresh, K., Nirmal, M. R., Senthil, N., \& Alias, L. M. (2009a). Protective effect of Withaferin-A on micronucleus frequency and detoxication agents during experimental oral carcinogenesis. African Journal of Traditional, Complementary and Alternative Medicines, 6(1), 1-8. https://doi.org/10.4314/ajtcam. v6i1.57067

Panjamurthy, K., Manoharan, S., Nirmal, M. R., \& Vellaichamy, L. (2009b). Protective role of Withaferin-A on immunoexpression of p53 and bcl-2 in 7,12-dimethylbenz(a)anthracene-induced experimental oral carcinogenesis. Investigational New Drugs, 27(5), 447-452. https:// doi.org/10.1007/s10637-008-9199-z

Patel, S. S., Savjani, J. K., Patel, S. S., \& Savjani, J. K. (2015a). Systematic review of plant steroids as potential anti-inflammatory agents: Current status and future perspectives. The Journal of Phytopharmacology, 4(42), 121-125.

Patel, D. P., Yan, T., Kim, D., Dias, H. B., Krausz, K. W., Kimura, S., \& Gonzalez, F. J. (2019). Withaferin A improves nonalcoholic steatohepatitis in mice. Journal of Pharmacology and Experimental Therapeutics, 371(2), 360-374. https://doi.org/10.1124/jpet.119.256792

Patel, N., Patel, P., Kendurkar, S. V., Thulasiram, H. V., \& Khan, B. M. (2015b). Overexpression of squalene synthase in Withania somnifera leads to enhanced withanolide biosynthesis. Plant Cell, Tissue and Organ Culture, 122(2), 409-420. https://doi.org/10.1007/s11240-015-0778-3

Patil, D., Gautam, M., Jadhav, U., Mishra, S., Karupothula, S., Gairola, S., Jadhav, S., \& Patwardhan, B. (2010). Physicochemical stability and biological activity of withania somnifera extract under real-time and accelerated storage conditions. Planta Medica, 76(5), 481-488. https://doi.org/10.1055/s-0029-1186220

Patil, D., Gautam, M., Mishra, S., Karupothula, S., Gairola, S., Jadhav, S., Pawar, S., \& Patwardhan, B. (2013). Determination of withaferin A and withanolide $A$ in mice plasma using high-performance liquid chromatography-tandem mass spectrometry: Application to pharmacokinetics after oral administration of Withania somnifera aqueous extract. Journal of Pharmaceutical and Biomedical Analysis, 80, 203-212. https://doi.org/10.1016/j.jpba.2013.03.001
Peddakkulappagari, C. S., Saifi, M. A., Khurana, A., Anchi, P., Singh, M., \& Godugu, C. (2019). Withaferin A ameliorates renal injury due to its potent effect on inflammatory signaling. Biofactors, 45(5), 750-762. https://doi.org/10.1002/biof.1534

Perestelo, N. R., Llanos, G. G., Reyes, C. P., Amesty, A., Sooda, K., Afshinjavid, S., Jiménez, I. A., Javid, F., \& Bazzocchi, I. L. (2019). Expanding the Chemical Space of Withaferin A by Incorporating Silicon to Improve Its Clinical Potential on Human Ovarian Carcinoma Cells. Journal of Medicinal Chemistry, 62(9), 4571-4585. https://doi. org/10.1021/acs.jmedchem.9b00146

Perou, C. M., Sørile, T., Eisen, M. B., Van De Rijn, M., Jeffrey, S. S., Ress, C. A., Pollack, J. R., Ross, D. T., Johnsen, H., Akslen, L. A., Fluge, Ø., Pergammenschlkov, A., Williams, C., Zhu, S. X., Lønning, P. E., Børresen-Dale, A. L., Brown, P. O., \& Botstein, D. (2000). Molecular portraits of human breast tumours. Nature, 406, 747-752. https:// doi.org/10.1038/35021093

Pires, N., Gota, V., Gulia, A., Hingorani, L., Agarwal, M., \& Puri, A. (2019). Safety and Pharmacokinetics of Withaferin-A in advanced stage high grade Osteosarcoma: A phase I trial. Journal of Ayurveda and Integrative Medicine, 11(1), 68-72. https://doi.org/10.1016/j. jaim.2018.12.008

Prabhakaran, Y., Dinakaran, S. K., Macharala, S. P., Ghosh, S., Karanam, S. R., Kanthasamy, N., \& Avasarala, H. (2012). Molecular docking studies of withanolides against Cox-2 enzyme. Pakistan Journal of Pharmaceutical Sciences, 25(3), 595-598.

Prakash, J., Gupta, S. K., Kochupillai, V., Singh, N., Gupta, Y. K., \& Joshi, S. (2001). Chemopreventive activity of Withania somnifera in experimentally induced fibrosarcoma tumours in swiss albino mice. Phytotherapy Research, 15(3), 240-244. https://doi.org/10.1002/ ptr.779

Pramanick, S., Roy, A., Ghosh, S., Majumder, H. K., \& Mukhopadhyay, S. (2008). Withanolide Z, a new chlorinated withanolide from Withania somnifera. Planta Medica, 74(14), 1745-1748. https://doi. org/10.1055/s-2008-1081357

Rai, A., Smita, S. S., Singh, A. K., Shanker, K., \& Nagegowda, D. A. (2013). Heteromeric and homomeric geranyl diphosphate synthases from catharanthus roseus and their role in monoterpene indole alkaloid biosynthesis. Molecular Plant, 6(5), 1531-1549. https://doi. org/10.1093/mp/sst058

Rao, S. R., \& Ravishankar, G. A. (2002). Plant cell cultures: Chemical factories of secondary metabolites. Biotechnology Advances, 20(2), 101-153. https://doi.org/10.1016/S0734-9750(02)00007-1

Ray, S., \& Jha, S. (2001). Production of withaferin A in shoot cultures of Withania somnifera. Planta Medica, 67(5), 432-436. https://doi. org/10.1055/s-2001-15811

Ray, S., \& Jha, S. (2001b). Production of withaferin A in shoot cultures of Withania somnifera. Planta Medica, 67(5), 432-436. https://doi. org/10.1055/s-2001-15811

Reshma, K., Rao, A. V., Dinesh, M., \& Vasudevan, D. M. (2007). Effect of withaferin, a radiosensitizer, on the erythrocyte antioxidants in carcinoma of uterine cervix. Biomedical Research, 18(3), 175-178.

Rout, J. R., Ram, S. S., Das, R., Chakraborty, A., Sudarshan, M., \& Sahoo, S. L. (2013). Copper-stress induced alterations in protein profile and antioxidant enzymes activities in the in vitro grown Withania somnifera L. Physiology and Molecular Biology of Plants, 19(3), 353-361. https://doi.org/10.1007/s12298-013-0167-5

Sabina, E. P., Chandel, S., \& Rasool, M. K. (2008). Inhibition of monosodium urate crystal-induced inflammation by withaferin A. Journal of Pharmacy and Pharmaceutical Sciences, 11(4), 46-55. https://doi. org/10.18433/j35k58

Sabina, E. P., Chandel, S., \& Rasool, M. K. (2009). Evaluation of analgesic, antipyretic and ulcerogenic effect of Withaferin A. International Journal of Integrative Biology, 6(2), 52-56.

Sabir, F., Mishra, S., Sangwan, R. S., Jadaun, J. S., \& Sangwan, N. S. (2013). Qualitative and quantitative variations in withanolides and expression of some pathway genes during different stages of morphogenesis in Withania somnifera Dunal. Protoplasma, 250(2), 539-549. https:// doi.org/10.1007/s00709-012-0438-y

Saha, S., Islam, M. K., Shilpi, J. A., \& Hasan, S. (2013). Inhibition of VEGF: a novel mechanism to control angiogenesis by Withania somnifera's key metabolite Withaferin A. In Silico Pharmacology, 1(11), 1-9. https://doi.org/10.1186/2193-9616-1-11

Samadi, A. K., Cohen, S. M., Mukerji, R., Chaguturu, V., Zhang, X., Timmermann, B. N., Cohen, M. S., \& Person, E. A. (2012). Natura 
withanolide withaferin A induces apoptosis in uveal melanoma cells by suppression of Akt and c-MET activation. Tumour Biology, 33(4), 1179-1189. https://doi.org/10.1007/s13277-012-0363-x

Samadi, A. K., Mukerji, R., Shah, A., Timmermann, B. N., \& Cohen, M. S. (2010). A novel RET inhibitor with potent efficacy against medullary thyroid cancer in vivo. Surgery, 148(6), 1228-1236. https://doi. org/10.1016/j.surg.2010.09.026

Samanta, S. K., Sehrawat, A., Kim, S. H., Hahm, E. R., Shuai, Y., Roy, R., Pore, S. K., Singh, K. B., Christner, S. M., Beumer, J. H., Davidson, N. E., \& Singh, S. V. (2017). Disease Subtype-Independent Biomarkers of Breast Cancer Chemoprevention by the Ayurvedic Medicine Phytochemical Withaferin A. Journal of the National Cancer Institute, 109(6), 1-13. https://doi.org/10.1093/jnci/djw293

Sangwan, R. S., Chaurasiya, N. Das, Lal, P., Misra, L., Tuli, R., \& Sangwan, N. S. (2008). Withanolide a is inherently de novo biosynthesized in roots of the medicinal plant Ashwagandha (Withania somnifera). Physiologia Plantarum, 133(2), 278-287. https:// doi.org/10.1111/j.1399-3054.2008.01076.x

Sayed, N., Khurana, A., Saifi, M. A., Singh, M., \& Godugu, C. (2019). Withaferin $A$ reverses bile duct ligation-induced liver fibrosis by modulating extracellular matrix deposition: Role of LOXL2/Snail1, vimentin, and NFKB signaling. BioFactors, 45(6), 959-974. https:// doi.org/10.1002/biof.1546

Senthil, K., Jayakodi, M., Thirugnanasambantham, P., Lee, S. C., Duraisamy, P., Purushotham, P. M., Rajasekaran, K., Nancy Charles, S., Mariam Roy, I., Nagappan, A. K., Kim, G. S., Lee, Y. S., Natesan, S., Min, T. S., \& Yang, T. J. (2015). Transcriptome analysis reveals in vitro cultured Withania somnifera leaf and root tissues as a promising source for targeted withanolide biosynthesis. BMC Genomics, 16(1). https://doi.org/10.1186/s12864-015-1214-0

Setty Balakrishnan, A., Nathan, A. A., Kumar, M., Ramamoorthy, S., \& Ramia Mothilal, S. K. (2017). Withania somnifera targets interleukin-8 and cyclooxygenase-2 in human prostate cancer progression. Prostate International, 5(2), 75-83. https://doi.org/10.1016/j.prnil.2017.03.002

Shah, N., Singh, R., Sarangi, U., Saxena, N., Chaudhary, A., Kaur, G., Kaul, S. C., \& Wadhwa, R. (2015). Combinations of Ashwagandha leaf extracts protect brain-derived cells against oxidative stress and induce differentiation. PLoS ONE, 10(3), 1-14. https://doi.org/10.1371/ journal.pone.0120554

Manoharan, S., Panjamurthy, K., Pugalendi, P., Balakrishnan, S., Rajalingam, K., Vellaichamy, L., \& Alias, L. M. (2008). Protective role of Withaferin-A on red blood cell integrity during 7,12-dimethylbenz[a] anthracene induced oral carcinogenesis. African Journal of Traditional, Complementary, and Alternative Medicines, 6(1), 94-102. https://doi. org/10.4314/ajtcam.v6i1.57079

Sharada, A. C., Solomon, F. E., Devi, P. U., Udupa, N., \& Srinivasan, K. K. (1996). Antitumor and radiosensitizing effects of withaferin a on mouse ehrlich ascites carcinoma in vivo. Acta Oncologica, 35(1), 95-100. https://doi.org/10.3109/02841869609098486

Sharma, A., Sharma, R., Chaudhary, P., \& Dobhal, M. P. (2011). Selective cytotoxicity of non-small cell lung cancer cells by the withaferin A-fortified root extract of Ashwagandha involves differential cell-cycle arrest and apoptosis. Phytopharmacology, 1(4), 54-70.

Sharma, S., \& Deep, S. (2020). In-silico drug repurposing for targeting SARS-CoV-2 Mpro. ChemRxiv, 2. https://doi.org/10.26434/ chemrxiv.12210845.v1

Sharma, V., Gupta, A. P., Bhandari, P., Gupta, R. C., \& Singh, B. (2007). A validated and densitometric HPTLC method for the quantification of withaferin-A and withanolide-A in different plant parts of two morphotypes of Withania somnifera. Chromatographia. 66, 801-804 (2007). https://doi.org/10.1365/s10337-007-0396-2

Shohat, B., Shaltiel, A., Ben-Bassat, M., \& Joshua, H. (1976). The effect of withaferin a, a natural steroidal lactone, on the fine structure of S-180 tumor cells. Cancer Letters, 2(2), 71-77. https://doi.org/10.1016/ S0304-3835(76)80014-6

Shono, T., Ono, M., Izumi, H., Jimi, S. I., Matsushima, K., Okamoto, T., Kohno, K., \& Kuwano, M. (1996). Involvement of the transcription factor NF-kappaB in tubular morphogenesis of human microvascular endothelial cells by oxidative stress. Molecular and Cellular Biology, 16(8), 4231-4239. https://doi.org/10.1128/mcb.16.8.4231

Shrilata, ST, K., CP, C., \& M, A. (2017). A Review Article of adaptogenic activity of Ashwaganda. Journal of Pharmaceutical and Scientific Innovation, 6(5), 94-98.

Siddharth, S., Muniraj, N., Saxena, N. K., \& Sharma, D. (2019). Concomitant inhibition of cytoprotective autophagy augments the efficacy of Withaferin a in hepatocellular carcinoma. Cancers, 11(4). https://doi. org/10.3390/cancers11040453

Singh, P., Guleri, R., Singh, V., Kaur, G., Kataria, H., Singh, B., Kaur, G., Kaul, S. C., Wadhwa, R., \& Pati, P. K. (2015). Biotechnological interventions in Withania somnifera (L.) Dunal. Biotechnology and Genetic Engineering Reviews, 31(1-2), 1-20. https://doi.org/10.108 0/02648725.2015.1020467

Singh, R., Singh, D. P., Gupta, P., Jain, P., Sanchita, Mishra, T., Kumar, A., Dhawan, S. S., \& Shirke, P. A. (2019). Nanoparticles alter the withanolide biosynthesis and carbohydrate metabolism in Withania somnifera (Dunal). Industrial Crops and Products, 127(11), 94-109. https://doi.org/10.1016/j.indcrop.2018.10.049

Sivanandhan, G., Arun, M., Mayavan, S., Rajesh, M., Mariashibu, T. S., Manickavasagam, M., Selvaraj, N., \& Ganapathi, A. (2012a). Chitosan enhances withanolides production in adventitious root cultures of Withania somnifera (L.) Dunal. Industrial Crops and Products, 37(1), 124-129. https://doi.org/10.1016/j.indcrop.2011.11.022

Sivanandhan, Ganeshan, Arun, M., Mayavan, S., Rajesh, M., Jeyaraj, M., Dev, G. K., Manickavasagam, M., Selvaraj, N., \& Ganapathi, A. (2012b). Optimization of elicitation conditions with methyl jasmonate and salicylic acid to improve the productivity of withanolides in the adventitious root culture of Withania somnifera (L.) dunal. Applied Biochemistry and Biotechnology, 168(3), 681-696. https://doi. org/10.1007/s12010-012-9809-2

Sivanandhan, Ganeshan, Kapil Dev, G., Jeyaraj, M., Rajesh, M., Muthuselvam, M., Selvaraj, N., Manickavasagam, M., \& Ganapathi, A (2013a). A promising approach on biomass accumulation and withanolides production in cell suspension culture of Withania somnifera (L.) Dunal. Protop/asma, 250(4), 885-898. https://doi. org/10.1007/s00709-012-0471-x

Sivanandhan, Ganeshan, Mariashibu, T. S., Arun, M., Rajesh, M., Kasthurirengan, S., Selvaraj, N., \& Ganapathi, A. (2011). The effect of polyamines on the efficiency of multiplication and rooting of Withania somnifera (L.) Dunal and content of some withanolides in obtained plants. Acta Physiologiae Plantarum, 33, 2279-2288. https://doi. org/10.1007/s11738-011-0768-y

Sivanandhan, Ganeshan, Rajesh, M., Arun, M., Jeyaraj, M., Kapil Dev, G. Arjunan, A., Manickavasagam, M., Muthuselvam, M., Selvaraj, N., \& Ganapathi, A. (2013b). Effect of culture conditions, cytokinins, methyl jasmonate and salicylic acid on the biomass accumulation and production of withanolides in multiple shoot culture of Withania somnifera (L.) Dunal using liquid culture. Acta Physiologiae Plantarum, 35(3), 715-728. https://doi.org/10.1007/s11738-012-1112-x

Sivanandhan, Ganeshan, Selvaraj, N., Ganapathi, A., \& Manickavasagam, M. (2014a). Enhanced biosynthesis of withanolides by elicitation and precursor feeding in cell suspension culture of Withania somnifera (L.) dunal in shake-flask culture and bioreactor. PLOS ONE, 9(8), e104005. https://doi.org/10.1371/journal.pone.0104005

Sivanandhan, Ganeshan, Selvaraj, N., Ganapathi, A., \& Manickavasagam, M. (2014b). Improved production of withanolides in shoot suspension culture of Withania somnifera (L.) Dunal by seaweed extracts. Plant Cell, Tissue and Organ Culture, 119(1), 221-225. https://doi. org/10.1007/s11240-014-0521-5

Sivanandhan, Ganeshan, Theboral, J., Kapil Dev, G., Selvaraj, N., Manickavasagam, M., \& Ganapathi, A. (2015). Effect of carbon and nitrogen sources on in vitro flower and fruit formation and withanolides production in Withania somnifera (L.) Dunal. Indian Journal of Experimental Biology, 53(3), 177-183.

Srivastava, S., Sanchita, Singh, R., Srivastava, G., \& Sharma, A. (2018) Comparative Study of Withanolide Biosynthesis-Related miRNAs in Root and Leaf Tissues of Withania somnifera. Applied Biochemistry and Biotechnology, 185(4), 1145-1159. https://doi.org/10.1007/ s12010-018-2702-x

Srtvastava, P., Tiwari, N., Yadav, A. K., Kumar, V., Shanker, K., Verma, R. K., Gupta, M. M., Gupta, A. K., \& Khanuja, S. P. S. (2008). Simultaneous quantification of withanolides in Withania somnifera by a validated high-performance thin-layer chromatographic method. Journal of AOAC International (pp. 1154-1161).

Stan, S. D., Hahm, E. R., Warin, R., \& Singh, S. V. (2008). Withaferin A causes FOXO3a- and Bim-dependent apoptosis and inhibits growth of human breast cancer cells in vivo. Cancer Research, 68(18), 7661-7669. https://doi.org/10.1158/0008-5472.CAN-08-1510

Straughn, A. R. (2020). Withaferin A : a potential therapeutic agent against 
COVID-19 infection. 1-5.

Sudeep, H. (2020). Molecular docking analysis of Withaferin A from Withania somnifera with the Glucose regulated protein 78 (GRP78) in comparison with the COVID-19 main protease. Bioinformation, 16(5), 411-417. https://doi.org/10.6026/97320630016411

Takshak, S., \& Agrawal, S. B. (2014). Effect of ultraviolet-B radiation on biomass production, lipid peroxidation, reactive oxygen species, and antioxidants in Withania somnifera. Biologia Plantarum, 58(2), 328-334. https://doi.org/10.1007/s10535-014-0390-0

Thaiparambil, J. T., Bender, L., Ganesh, T., Kline, E., Patel, P., Liu, Y., Tighiouart, M., Vertino, P. M., Harvey, R. D., Garcia, A., \& Marcus, A. I. (2011). Withaferin A inhibits breast cancer invasion and metastasis at sub-cytotoxic doses by inducing vimentin disassembly and serine 56 phosphorylation. International Journal of Cancer, 129(11), 2744-2755. https://doi.org/10.1002/ijc.25938

Tiruveedi, V. L., Bale, S., Khurana, A., \& Godugu, C. (2018). Withaferin A, a novel compound of Indian ginseng (Withania somnifera), ameliorates Cerulein-induced acute pancreatitis: Possible role of oxidative stress and inflammation. Phytotherapy Research, 32(12), 2586-2596. https:// doi.org/10.1002/ptr.6200

Tiwari, S., Atluri, V. S. R., Yndart Arias, A., Jayant, R. D., Kaushik, A., Geiger, J., \& Nair, M. N. (2018). Withaferin A suppresses beta amyloid in app expressing cells: studies for tat and cocaine associated neurological dysfunctions. Frontiers in Aging Neuroscience, 10, 1-12. https://doi.org/10.3389/fnagi.2018.00291

Tong, X., Zhang, H., \& Timmermann, B. N. (2011). Chlorinated withanolides from Withania somnifera. Phytochemistry Letters, 4(4), 411-414. https://doi.org/10.1016/j.phytol.2011.04.016

Tripathi, M. K., Singh, P., Sharma, S., Singh, T. P., Ethayathulla, S., \& Kaur, P. (2020). Identification of bioactive molecule from Withania somnifera ( Ashwagandha ) as SARS-CoV-2 main protease inhibitor as SARSCoV-2 main protease inhibitor. Journal of Biomolecular Structure and Dynamics, 0(0), 1-14. https://doi.org/10.1080/07391102.2020 .1790425

Tripathi, S., Sangwan, R. S., Narnoliya, L. K., Srivastava, Y., Mishra, B., \& Sangwan, N. S. (2017). Transcription factor repertoire in Ashwagandha (Withania somnifera) through analytics of transcriptomic resources: Insights into regulation of development and withanolide metabolism. Scientific Reports, 7(1). https://doi.org/10.1038/s41598-017-14657-6

Uma Devi, P., Kamath, R., \& Satish Rao, B. S. (2000). Radiosensitization of a mouse melanoma by withaferin A: In vivo studies. Indian Journal of Experimental Biology, 38(5), 7432-7443.

Vadloori, B., Sharath, A. K., Prabhu, N. P., \& Maurya, R. (2018). Homology modelling, molecular docking, and molecular dynamics simulations reveal the inhibition of Leishmania donovani dihydrofolate reductase thymidylate synthase enzyme by Withaferin - A. BMC Research Notes, 11, 1-7. https://doi.org/10.1186/s13104-018-3354-1

Vaishnavi, K., Saxena, N., Shah, N., Singh, R., Manjunath, K., Uthayakumar, M., Kanaujia, S. P., Kaul, S. C., Sekar, K., \& Wadhwa, R. (2012). Differential Activities of the two closely related withanolides, Withaferin $A$ and Withanone: Bioinformatics and Experimental Evidences. PLoS ONE, 7(9), 1-13. https://doi.org/10.1371/journal.pone.0044419

Van Herck, S., Hassannia, B., Louage, B., Pita Compostizo, R., De Coen, R., Vanden Berghe, W., Vanden Berghe, T., \& De Geest, B. G. (2019). Water-soluble withaferin A polymer prodrugs via a drug-functionalized RAFT CTA approach. European Polymer Journal, 110, 313-318. https://doi.org/10.1016/j.eurpolymj.2018.11.043
Vanden Berghe, W., Sabbe, L., Kaileh, M., Haegeman, G., \& Heyninck, K. (2012). Molecular insight in the multifunctional activities of Withaferin A. In Biochemical Pharmacology (pp. 1282-1291). https:// doi.org/10.1016/j.bcp.2012.08.027

Vasconsuelo, A., \& Boland, R. (2007). Molecular aspects of the early stages of elicitation of secondary metabolites in plants. Plant Science, 172(5), 861-875. https://doi.org/10.1016/j.plantsci.2007.01.006

Vedi, M., Rasool, M., \& Sabina, E. P. (2014). Amelioration of bromobenzene hepatotoxicity by Withania somnifera pretreatment: Role of mitochondrial oxidative stress. Toxicology Reports, 1, 629-638. https://doi.org/10.1016/j.toxrep.2014.08.009

Wadhwa, R., Dhanjal, J. K., Kumar, V., Kaul, S. C., \& Sundar, D. (2020). why ashwagandha for prevention and treatment of COVID-19? Applied Microbiology, 6(176), 1-4. https://doi.org/10.35248/24719315.20.6.176

Wang, M., Wang, D., Zhang, Q., Chai, J., Peng, Y., \& Cai, X. (2017). Identification and cytochemical immunolocalization of acetyl-CoA acetyltransferase involved in the terpenoid mevalonate pathway in Euphorbia helioscopia laticifers. Botanical Studies, 58(62), 1-11. https://doi.org/10.1186/s40529-017-0217-3

Wijeratne, E. M. K., Xu, Y. M., Scherz-Shouval, R., Marron, M. T., Rocha, D. D., Liu, M. X., Costa-Lotufo, L. V., Santagata, S., Lindquist, S., Whitesell, L., \& Gunatilaka, A. A. L. (2014). Structureactivity relationships for withanolides as inducers of the cellular heatshock response. Journal of Medicinal Chemistry, 57(7), 2851-2863. https://doi.org/10.1021/jm401279n

Xu, Y. M., Gao, S., Bunting, D. P., \& Gunatilaka, A. A. L. (2011). Unusual withanolides from aeroponically grown Withania somnifera. Phytochemistry, 72(6), 518-522. https://doi.org/10.1016/j. phytochem.2010.12.020

Yadav, D. K., Kumar, S., Saloni, Singh, H., Kim, M. H., Sharma, P., Misra, S., \& Khan, F. (2017). Molecular docking, QSAR and ADMET studies of withanolide analogs against breast cancer. Drug Design, Development and Therapy, 11, 1859-1870. https://doi.org/10.2147/ DDDT.S130601

Yan, X., Huang, G., Liu, Q., Zheng, J., Chen, H., Huang, Q., Chen, J., \& Huang, H. (2017). Withaferin a protects against spinal cord injury by inhibiting apoptosis and inflammation in mice. Pharmaceutical Biology, 55(1), 1171-1176. https://doi.org/10.1080/13880209.201 7.1288262

Yang, H., Shi, G., \& Dou, Q. P. (2007). The tumor proteasome is a primary target for the natural anticancer compound Withaferin A isolated from "Indian Winter Cherry." Molecular Pharmacology, 71(2), 426-437. https://doi.org/10.1124/mol.106.030015

Yousuf, S. K., Majeed, R., Ahmad, M., Sangwan, P. L., Purnima, B., Saxsena, A. K., Suri, K. A., Mukherjee, D., \& Taneja, S. C. (2011). Ring A structural modified derivatives of withaferin $A$ and the evaluation of their cytotoxic potential. Steroids, 76((10-11).), 1213-1222. https:// doi.org/10.1016/j.steroids.2011.05.012

Yu, Y., Hamza, A., Zhang, T., Gu, M., Zou, P., Newman, B., Gunatilaka, A. A. L., Whitesell, L., Zhan, C., \& Sun, D. (2011). Withaferin A Targets Heat Shock Protein 90 in Pancreatic Cancer Cells. Biochemical Pharmacology, 79(4), 542-551. https://doi.org/10.1016/j.bcp.2009.09.017

Zhang, X., Sun, S., Nie, X., Boutté, Y., Grison, M., Li, P., Kuang, S., \& Men, S. (2016). Sterol methyl oxidases affect embryo development via auxinassociated mechanisms. Plant Physiology, 17(1), 468-482. https:// doi.org/10.1104/pp.15.01814 